\title{
Sugar Beet Extract Acts as a Natural Bio-Stimulant for Physio-Biochemical analysis of Hordeum Vulgare L. under Induced Salinity Stress
}

Noor Ali Shah ${ }^{1}$, ${ }^{*}$ Sami Ullah ${ }^{1}$, Muhammad Nauman Khan ${ }^{2}$, Sajjad Ali², Muhammad Adnan ${ }^{3}$, Amjad Ali ${ }^{4}$, Muhammad Ali ${ }^{5}$, Ajmal Khan ${ }^{5}$, Said Hassan ${ }^{5}$, Wisal Muhammad Khan ${ }^{6}$

${ }^{1}$ Department of Botany, University of Peshawar, 25120, Pakistan

${ }^{2}$ Department of Botany, Bacha Khan University, Charsadda, 24420, Pakistan

${ }^{3}$ Department of Chemistry, Bacha Khan University, Charsadda, 24420, Pakistan

${ }^{4}$ Department of Sustainable Crop Production, Università Cattolica del Sacro Cuore, Via Emilia Parmense, 84

29122 Piacenza

${ }^{5}$ Institute of Biotechnology and Microbiology, Bacha Khan University, Charsadda, 24420, Pakistan

${ }^{6}$ Department of Botany, Islamia College Peshawar, 25120, Pakistan

*Corresponding Author: sami_jan69@yahoo.com

Author contribution: All authors contributed equally to this work

Acknowledgements: We are highly acknowledged to the Department of Botany, University of Peshawar for providing all facilities regarding this work.

\section{Abbreviations}

$\mathrm{SBE}=$ sugar beet extract, $\mathrm{CVE}=$ coefficient of velocity of emergence, $\mathrm{MET}=$ mean emergence time, $\mathrm{GE}=$ germination energy, $\mathrm{TGI}=$ timson germination index, $\mathrm{GRI}=$ germination rate index, $\mathrm{POD}=$ Peroxidase, $\mathrm{MDA}=$ Malondialdehyde, $\mathrm{SOD}=$ Superoxide dismutase, $\mathrm{H}_{2} \mathrm{O}_{2}=$ Hydrogen peroxide, $\mathrm{ROS}=$ reactive oxygen species, AsA= Ascorbic acid, $\mathrm{CAT}=$ Catalase, $\mathrm{TSS}=$ total soluble sugars $(\mathrm{TSS}), \mathrm{G1}=$ Germinated seed percentage at day first. 


\section{Abstract}

Change in climate of the entire globe due to elevated temperature and minimum annual rainfall in barren zone frequently leads to salinity of soil. The current study was aimed to evaluate the importance of sugar beet extract (SBE) as a bio-stimulant to improve the adverse damages of induced salinity stress $(40 \mathrm{mM})$ on growth, oosmolytes and antioxidant defense system of barley (Hordeum vulgare L.). Pot experiment was carried in green house under different concentrations of SBE $(10 \%, 20 \%, 30 \%, 40 \%, 50 \%)$ pre-soaked seeds of Hordeum vulgare for 5 hours SBE was analyzed for glycine betaine $(100 \mathrm{mmol} / \mathrm{kg})$, betalains $(1.3 \mathrm{mg} / \mathrm{l})$, phenolics $(1.30 \mathrm{~g} / 100 \mathrm{ml})$, flavonoids $(0.59 \mathrm{mg} / \mathrm{ml})$, carotenoids $(0.23 \mathrm{ml} / 100 \mathrm{ml})$, vitamin $\mathrm{E}(0.002 \%)$, vitamin C $(8.04 \mathrm{~g} / 100 \mathrm{ml})$, sugar $(8 \mathrm{~g} / 100 \mathrm{ml})$, protein $(1.39 \mathrm{mg} / 100 \mathrm{ml})$, and oxalic acid (38mg/100ml) while $\mathrm{Ca}(13.72 \mathrm{mg} / \mathrm{l}), \mathrm{Mg}(7.121 \mathrm{mg} / \mathrm{l})$ and $\mathrm{K}(11.45 \mathrm{mg} / \mathrm{l})$ contents were also determined. We found significant improvement in germination parameters of Hordeum vulgare L. via SB extract on coefficient of velocity of emergence (CVE), mean emergence time (MET), germination energy (GE), timson germination index (TGI), germination rate index (GRI) and time to $50 \%$ emergence $\left(\mathrm{E}_{50}\right)$ under induced salinity stress. However, photosynthetic pigments, e.g., chlorophyll and carotenoids were enhanced using 40\% SB extract, soluble sugar, protein, proline, POD, MDA with 50\% SB extract while SOD and $\mathrm{H}_{2} \mathrm{O}_{2}$ in $20 \% \mathrm{SBE}$, respectively. Our findings suggested that SB extract promotes both agronomical and physiological attributes, is a positive way to enhance our economy by increasing crop yields in arid and semi-arid areas along with plant tolerance to under induced salinity stress.

Key words: Seed priming. Salinity stress. Photosynthetic pigments. Antioxidants. Hordeum vulgare L.

\section{Highlights}

The recent study is of utmost importance owing to the following reasons:

$>$ Changes in climatic condition results in salinity, droughts, floods, earthquakes, fluctuation in temperature and other environmental hazards.

$>$ Salinity stress has myriad of damaging effects on crop growth and productivity and becoming a global issue of major concern especially in the Asian countries including Pakistan. Statistical analysis showed that 6.30 million of lands is affected with salinity.

Barley (Hordeum Vulgare L.) being an important crop of economic and nutritional value has been facing salinity stress condition in Pakistan, resulting in productivity reduction and ultimately paving the way for food scarcity and crippling economy. 
$>$ The sole purpose of this research article is to assess and ameliorate the physio-biochemical responses via application of sugar beet extract as bio-stimulants in Barley (Hordeum Vulgare L.) grown under induced salinity stress; in order to cope with the dire consequences of salinity stress especially in the southern areas of Pakistan being badly affected by salt stress.

$>$ Furthermore, there is a great need for adaptive measures suggested by the present research and other findings made by researchers in pursuit of tackling this alarming global menace.

\section{Introduction}

By the end of 2050, abiotic stresses such as salinity, drought and temperature will lead to huge losses in crop and food production (Ahmed et al. 2020; Hawrylak et al. 2019). The beginning of the 21 st century is marked by global shortage of water and soil salinity (Sanders 2020; Fedoroff et al. 2010). Salinity is one of the main environmental factors which limiting plants productivity (Munns and Tester 2008). Worldwide, salinity has been reported that about $7.0 \%$ (which includes an estimated area of about 77 Mha) of the world's land surface is occupied by various soils affected by salinity (Kashif et al. 2020). Salinity causes many abnormal changes in the morphological and physiological functioning of plant cells due to sodium and chloride ions in cells, disturbs the level of minerals and reduces the water potential of the soil for sowing by a high osmotic potential causing high osmotic stress (Zhu et al 2020). Due to salinity, synthesis of lipids and protein along with photosynthesis are badly affected in plants (Javed et al. 2020). To respond to such reactive oxygen species (ROS), plants immediately regulate their antioxidant defense mechanism by activating antioxidant enzymes activities; such as SOD, POD, CAT (Amirjani 2011). Catalase enzyme has a greater importance to convert $\mathrm{H}_{2} \mathrm{O}_{2}$ into useful water and oxygen, while peroxidases break down $\mathrm{H}_{2} \mathrm{O}_{2}$ through the oxidation of the cosubstrate which includes phenolic compounds and other antioxidants. Similarly, the ascorbate peroxidase enzyme synthesizes ascorbic acid (AsA) as an electron donor in the antioxidant process that increases $\mathrm{H}_{2} \mathrm{O}_{2}$ (Prasad et al. 2009).

Barley belongs to the family Poaceae and is the $4^{\text {th }}$ most important cereal crop (Gorzolka et al. 2016). It is the $4^{\text {th }}$ most important and stress tolerant cereal crop globally, after wheat, maize and rice (Imran et al. 2020). About 6.30 million of lands is affected with salinity (Economic survey of Pakistan 2017). According to an estimate about $20 \%$ of all irrigated and cultivated lands (equivalent to 62 million ha) are negatively affected by salt stress at present time (Javed et al. 2020). Production of barley fluctuated substantially in the history of Pakistan. It occupies an area of 84.1 thousand hectares with a production of 71.4 thousand tons (Ali et al. 2020). Being a simple and cost effective, seed priming technique has been used to improve plant growth, germination and 
enhanced seedling's vigor (Zhang and Rue 2014). Application of SBE and GB on the Solanum melongena L. plants to alleviate salinity stress. Since sugar beet extract contains important nutrients like AsA, GB, vitamin E, sugars and amino acids, etc. Also, it can be used as a cheaper source of GB to improve and protect plants from the lethal effect of salt stress (Abbas et al. 2010; Ahanger et al. 2020). All the compounds in sugar beet, that is, play a vital role as a bio-stimulant in plant life during stressful conditions. Seed priming technique, best pregermination seed treatment has been revealed to boost seedling and yield germination (Nasri et al. 2013). The application of SBE as bio-stimulants is boosting speedily in agronomic crops for valuable effects under stressful conditions (Pinheiro et al. 2018; Mahdy et al. 2020). It was assumed priming of seeds with SBE could lower the damaging effects of salinity stress on seed seedling emergence, germination, and establishment. Therefore, the present experiment was performed to evaluate the capability of seed pre-sowing with SBE to regulate barley seed germination under $40 \mathrm{mM} \mathrm{NaCl}$ stress. In addition, to explore the degree of efficacy of SBE responses in terms of physiological and biochemical attributes were kept in focus to find out a viable strategy for blocking oxidative stress in barley.

\section{Material and Methods}

\subsection{Formation of Sugar beet extract (SBE)}

The fresh roots of Beta vulgaris L. were obtained from local market, grind to obtain juice and stored at $10^{\circ} \mathrm{C}$. Different concentrations of SBE i.e. $(10 \%, 20 \%, 30 \%, 40 \%$ and $50 \% \mathrm{v} / \mathrm{v})$ were then prepared and applied for the treatments.

\subsection{Estimation of glycine betaine (GB) and Betalain content}

SB extract was analyzed for glycine betaine (GB) by following the methodology of Grieve and Grattan (1983). Betalain content was investigated by the following method Nilsson (1970), the absorbance of betalains were measured at 538 and $480 \mathrm{~nm}$ using the method of Cai (2005) equation.

$$
\text { Betalain content }=[\mathrm{A} \times \mathrm{DF} \times \mathrm{MW} \times 1000 / \varepsilon \times \mathrm{L}](\mathrm{mg} \mathrm{L})
$$

$\mathrm{DF}=$ dilute factor, $\mathrm{MW}=$ molecular weight, and $\varepsilon$ is the extinction coefficient, for indicaxanthin and betanin, i.e. 48,000 and $60,0001 / \mathrm{mol}$.

\subsection{Estimation of phenolic and flavonoid content}

Sugar beet extract was examined phenolics in SBE following method of Waterhouse (2002) with optical density at $765 \mathrm{~nm}$. Similarly, flavonoid content was calculated as per described by the methodology of Bushra et 
al. (2009) by reacting the dilute $\mathrm{SBE}$ with $0.5 \%$ of $\mathrm{NaNO}_{2}$ and $10 \% \mathrm{AlCl}_{3}$. After that, $0.2 \mathrm{ml}$ of sodium hydroxide was added. optical density was recorded at $415 \mathrm{~nm}$.

\subsection{Estimation of carotenoid content}

Carotenoid contents in sugar beet extract were determined by Mohdaly et al. (2010). Using spectrophotometer and measured at $450 \mathrm{~nm}$ by the following equation.

$$
\beta \text {-carotene }=\mathrm{A} \times \mathrm{df} \times \mathrm{V} / \mathrm{E} 1 \% 1 \mathrm{~cm} \times \mathrm{w}
$$

Here, $\mathrm{df}=$ dilution factor, $\mathrm{V}=$ volume $(\mathrm{ml}), \mathrm{E} 1 \%$ = coefficient of absorbency for petroleum ether was (2592)1 $\mathrm{cm}, \mathrm{w}=$ weight of sample $(\mathrm{g}), \mathrm{A}=$ absorbance.

\subsection{Estimation of alpha-tocopherol (Vitamin E) and ascorbic acid}

\section{(Vitamin C)}

According to Backer et al. (1980) method was used to study alpha-tocopherol content in sugar beet extract at $520 \mathrm{~nm}$ whereas, following the standard protocol of Mukherjee and Choudhuri (1983) ascorbic acid was determined in sugar beet extract. The absorbance of vitamin $\mathrm{C}$ was measured at $530 \mathrm{~nm}$.

\subsection{Estimation of total soluble sugars (TSS) and oxalic acid content}

Total soluble sugars were investigated by using the method of Dubois et al. (1956). Similarly, oxalic acid content in SBE was estimated by per manganese method. Oxalic acid concentrations were determined using a curve generated by an oxalic acid.

\subsection{Estimation of SBE minerals and $\mathrm{pH}$}

Flame photometer was used for the estimation of $\mathrm{Ca}, \mathrm{P}, \mathrm{K}$, and $\mathrm{Mg}$ contents, while Atomic Absorption Spectrometry (AAS700, Perkin Elmer, USA), and was applied to determine $\mathrm{Mn}, \mathrm{Fe}, \mathrm{Cu}$ and Ni, contents in SBE, Centralized Resource Laboratory (CRL), University of Peshawar, Pakistan. However, $\mathrm{pH}$ of the sugar beet extract measured with pH meter (WTW Inolab 7110).

\subsection{Site description and experimental design}

Field experiment was carried out at Department of Botany, University of Peshawar (34 $1^{\prime} 33.3012^{\prime \prime} \mathrm{N}$ and $71^{\circ} 33^{\prime} 36.4860^{\prime \prime}$ E.) during barley growing season in 2018. Barley seeds (Hordeum vulgare L.) were collected from National Agricultural Research Center (NARC), Islamabad, Pakistan. Intact seeds of uniform shape and size were surface sterilized $0.3 \%$ sodium hypochlorite for three minutes and the rinsed and soaked in sugar beet extract 
with different concentrations of SBE such as, 10\%, 20\%, 30\%, 40\% and 50\% for 5 hours. The seeds were sown in earthen pots $(20 \mathrm{~cm}$ height $)$, with upper/lower diameter $(18 \mathrm{~cm})$ filled with $4 \mathrm{~kg}$ of sandy and loamy $(2: 1)$ having pH (6.0), EC (2.41ds/m), Organic Carbon (C) $22.6 \mathrm{~g} \mathrm{~kg}^{-1}$ (Nelson and Sommers 1983), Nitrogen (N) content 3.09 $\mathrm{g} \mathrm{kg}^{-1}$ (Keeney and Nelson, 1983), Potassium (K) available $92.3 \mathrm{mg} \mathrm{kg}^{-1}$ (Nelson and Heidel 1952) and Phosphorus (P) $8.0 \mathrm{mg} \mathrm{kg}^{-1}$ (Jacson et al. 1973) and percent moisture content of 46\%. Each pot was kept at $15 \mathrm{~cm}$ apart in a complete randomized design and were protected from rain. About 10 seeds of barley have been sown in each pot. Experiment was divided into 11 treatments $(\mathrm{T} 1=\mathrm{Control}$ (untreated), $\mathrm{T} 2=10 \% \mathrm{SBE}, \mathrm{T} 3=10 \% \mathrm{SBE}+40 \mathrm{mM}$ $\mathrm{NaCl}, \mathrm{T} 4=20 \% \mathrm{SBE}, \mathrm{T} 5=20 \% \mathrm{SBE}+40 \mathrm{mM} \mathrm{NaCl}, \mathrm{T} 6=30 \% \mathrm{SBE}, \mathrm{T} 7=30 \% \mathrm{SBE}+40 \mathrm{mM} \mathrm{NaCl}, \mathrm{T} 8=40 \%$ $\mathrm{SBE}, \mathrm{T} 9=40 \% \mathrm{SBE}+40 \mathrm{mM} \mathrm{NaCl}, \mathrm{T} 10=50 \% \mathrm{SBE}, \mathrm{T} 11=50 \% \mathrm{SBE}+40 \mathrm{mM} \mathrm{NaCl}$ ) with three replicates per treatment. Hand weeding, watering and plant thinning were done, and the seedlings were exposed to proper sunlight for healthier growth. Salinity stress $(40 \mathrm{mM} \mathrm{NaCl})$ was applied after 25 days of post germination, while plant samples for the determination of growth and physiological parameters were collect after 10 days of saline treatment and preserved in refrigerator at $4^{\circ} \mathrm{C}$.

\subsection{Elemental analysis of plant foliar material}

EDX technique (INCA100/ Oxford instruments, U.K.) was performed for elemental analysis in barley leaves including carbon (C), oxygen (O), nitrogen (N), Sulphur (S), Phosphorus (P), Sodium (Na), Calcium (Ca), Magnesium (Mg), Potassium (K), Chlorine (Cl) and Silicon (Si).

\subsection{Agronomic characteristics}

\subsubsection{Mean Germination Time (MGT)}

Mean germination time for seed emergence investigated by Kader (2005). Greater will be the inhabitants germinated lower is mean germination time.

$$
\operatorname{MET}=\frac{\sum f x}{\sum f}
$$

Hence " $\mathrm{f}$ " shows the numbers of seed germinated on $\mathrm{X}$ days.

\subsubsection{Time to $50 \%$ Germination (T50\%)}

Time to 50\% germination planned by the Vujosevic et al. (2018).

$$
T_{50}=t_{i}+\frac{N / 2-n_{i}}{n_{j}-n_{i}}\left(t_{j}-t_{i}\right) \quad \text { Eq. } 2
$$


Hence "N" refers to the final emerged seeds number, where nj and ni are inconsistent number of seeds germinated by the adjoining count at $\mathrm{tj}$ and ti, correspondingly, when $\mathrm{ni}<\mathrm{N} / 2>\mathrm{Nj}$.

\subsubsection{Germination Rate Index (GRI)}

Germination rate index was calculated by Kaydan and Yagmur (2008).

$$
\mathrm{GRI}=\frac{\mathrm{G}_{1}}{1}+\frac{\mathrm{G}_{2}}{2}+\frac{\mathrm{G}_{3}}{3}+\ldots+\frac{\mathrm{G}_{\mathrm{X}}}{\mathrm{X}} \quad \text { Eq. } 3
$$

Hence "G1" is the germinated seed percentage at day first and "G2" is germinated seed percentage at second day after sowing.

\subsubsection{Coefficient of Velocity of Emergence (CVE)}

Coefficient of velocity of emergence was determined by the method of Kader (2005).

$$
\mathrm{CVE}=\frac{N_{1}+N_{2}+N_{3}+\ldots+N_{X}}{100}\left(N_{1} T_{1}+N_{2} T_{2}+N_{3} T_{3}+\ldots+N_{X} T_{X}\right) \quad \text { Eq. } 4
$$

Hence " $n$ " is the number of seed germinated per/day while T represents the time.

\subsubsection{Timson Germination Index (TGI), Germination Energy (GE)}

Timson germination index and Germination energy was measured by the method of Al-Ansari and Siksi (2016).

$$
\text { TGI }=\Sigma G / T
$$

Hence $\mathrm{G}$ is the germination percentage per day, while $\mathrm{T}$ is the entire germination period.

Germination energy was determined by the following formula Al-Ansari and Siksi (2016).

$$
\mathrm{GE}=\frac{X_{1}}{Y_{1}}+\frac{X_{2}-X_{1}}{Y_{2}}+\frac{X_{3}-X_{2}}{Y_{3}}+\ldots+\frac{X_{n}-X_{n-1}}{Y_{n}} \quad \text { Eq.6 }
$$

Hence, $X_{n}=$ numbers of seed germination on last ( $n$ th) counting date and $Y_{n}$ represents the number of days from sowing to last (nth) counting date.

\subsection{Physiological and biochemical analysis of plant foliar}

\section{material}

\subsubsection{Determination of Chlorophyll and Carotenoid Content}

Chlorophyll and carotenoid contents were determined by the method of Marcinska et al. (2012) with some modifications. Foliar material of $0.2 \mathrm{~g}$ was chopped in $80 \%$ acetone and incubated for 24 hours in dark then 
centrifuged. Absorbance values for chlorophyll "a" at $649 \mathrm{~nm}$, chlorophyll "b at $663 \mathrm{~nm}$ and carotenoid at 470 nm were observed against $80 \%$ acetone blank through spectrophotometer.

\subsubsection{Estimation of Osmolytes Content}

Leaf soluble sugar content was evaluated by the methodology of Dubois et al. (1956). Foliar material of $0.5 \mathrm{~g}$ was grounded in $5 \mathrm{ml}$ distilled water and centrifuged for 10 minutes. About $4 \mathrm{ml}$ of $35 \%$ concentrated $\mathrm{H}_{2} \mathrm{SO}_{4}$ was added to $1 \mathrm{ml}$ supernatant its optical density was found at $490 \mathrm{~nm}$.

Total proline content was measured by the methodology of Plazek et al. (2013). $0.5 \mathrm{~g}$ of fresh leaves were grounded 3\% (10 ml) sulfosalicylic acid and filtered. After filtration, $2 \mathrm{ml}$ of the filtrate was dissolved in 2 $\mathrm{ml}$ acid ninhydrin (40 $\mathrm{ml}$ glacial acetic acid $+1.87 \mathrm{~g}$ ninhydrin $+30 \mathrm{ml}$ of $6 \mathrm{M}$ phosphoric acid $)$ and glacial acetic acid in a test tube and warm for $1 \mathrm{~h}$ at $100^{\circ} \mathrm{C}$. Solution extraction was completed with toluene (4 ml) and OD was measured at $520 \mathrm{~nm}$.

\subsubsection{Estimation of Soluble Protein (SP) and Hydrogen Peroxide Content $\left(\mathrm{H}_{2} \mathrm{O}_{2}\right)$}

Soluble protein was found by the standard protocol of Rostami and Ehsanpaur (2009) with some modifications. $0.5 \mathrm{~g}$ foliar material was grounded in $1 \mathrm{ml}$ phosphate buffer solution $(\mathrm{pH} 7.0)$. After homogenation for $10 \mathrm{~min}$, about $0.1 \mathrm{ml}$ extract mixed $0.9 \mathrm{ml}$ distilled water and $1 \mathrm{ml}$ reagent in $40 \mathrm{ml}$ distilled water $(0.1 \mathrm{~N}$ sodium hydroxide, $0.75 \mathrm{~g}$ sodium carbonate, $0.37 \mathrm{~g}$ sodium potassium tartrate). By shaking and adding $0.1 \mathrm{ml}$ foline phenol was kept for incubation of $30 \mathrm{~min}$ and the absorbance was measured at $650 \mathrm{~nm}$ over spectrophotometer.

$\mathrm{H}_{2} \mathrm{O}_{2}$ concentration was investigated by Velikova et al. (2000). Fresh foliar material (0.5 gm) was chopped in $5 \mathrm{ml}$ trichloro acetic acid and centrifuged for $10 \mathrm{~min}$. About $0.5 \mathrm{ml}$ of the supernatant was dissolved in $0.5 \mathrm{ml}$ phosphate buffer and $1 \mathrm{ml}$ potassium iodide reagent. Optical density was determined at $390 \mathrm{~nm}$.

\subsubsection{Determination of Antioxidant Enzymes}

Leaf MDA content was estimated by Zhang and Huang (2013). $0.25 \mathrm{~g}$ of leaves were homogenized in $3 \mathrm{ml}$ of $1.0 \%$ Trichloro acetic acid and centrifuge for 10 minutes. $1 \mathrm{ml}$ of the supernatant was mixed with $0.5 \%$ (4 ml) 2-thiobarbituric acid and heated for one hour at $95^{\circ} \mathrm{C}$, then cooled with ice for 10 minutes and its optical density was determined at $532 \mathrm{~nm}$. 
SOD activity was determined by the method of Wang et al. (2014) with a little bit change. 3 ml reaction mixture contained $0.1 \mathrm{ml}$ supernatant, $0.72 \mathrm{ml}$ methionine $(58 \mathrm{mg}), 0.72 \mathrm{ml}$ nitroblue tetrazolium $(1.89 \mathrm{mg}), 0.72$ $\mathrm{ml}$ ethylene diamine tetra acetic acid $(1.1 \mathrm{mg})$ and $0.72 \mathrm{ml}$ riboflavin $(0.02 \mathrm{mg})$ in $120 \mathrm{ml}$ distilled water and then kept for incubation in dark and light period of $30 \mathrm{~min}$. Optical density was determined by spectrophotometer at $560 \mathrm{~nm}$.

POD activity of plant foliar material was performed by the methodology of Asthir et al. (2009). $0.5 \mathrm{~g}$ fresh leaves were chopped with $2 \mathrm{ml}$ solution comprises of $12.5 \mathrm{~g}$ polyvinyl pyrrolidine, $4.6 \mathrm{~g}$ ethylene diamine tetra acetic acid, $0.2 \mathrm{ml}$ phosphate buffer solution with $7.0 \mathrm{pH}$ in $125 \mathrm{ml}$ of distilled water and then centrifuged for $20 \mathrm{~min} .3 \mathrm{ml}$ reaction mixture contained supernatant $(0.1 \mathrm{ml})$, methyl ethyl sulfonic acid buffer $(1.3 \mathrm{ml})$, phenyl diamine $(0.1 \mathrm{ml})$ and a drop of $\mathrm{H}_{2} \mathrm{O}_{2}(3 \%)$. Optical density was measured at $485 \mathrm{~nm}$ by spectrophotometer.

\subsection{Statistical Analysis}

The statistical analysis was three factors (barley, SBE, salinity) which arranged in CRD. Data collected for various germination attributes, physiological and biochemical components by using IBM SPSS Statistics 22. Mean separation and standard deviation were determined by Tukey’s test.

\section{Results}

The preliminary work was planned to determine the role of SBE as bio-stimulants under different percent concentrations. Various bio-chemical compounds were investigated in SBE included glycine betaine $(100 \mathrm{mmol} / \mathrm{kg})$, betalains $(1.3 \mathrm{mg} / \mathrm{l})$, phenolics $(1.30 \mathrm{~g} / 100 \mathrm{ml})$, flavonoids $(0.59 \mathrm{mg} / \mathrm{ml})$, carotenoids $(0.23 \mathrm{ml} / 100 \mathrm{ml})$, vitamin E (0.002\%), vitamin C $(8.04 \mathrm{~g} / 100 \mathrm{ml})$, sugar $(8 \mathrm{~g} / 100 \mathrm{ml})$, protein $(1.39 \mathrm{mg} / 100 \mathrm{ml})$, and oxalic acid, while the concentrations of various nutrient minerals such as $\mathrm{Ca}(13.72 \mathrm{mg} / \mathrm{l}), \mathrm{Mg}(7.121 \mathrm{mg} / \mathrm{l}), \mathrm{K}(11.45 \mathrm{mg} / \mathrm{l}), \mathrm{Na}(3.098 \mathrm{mg} / \mathrm{l})$, Fe (1.501 mg/l), Cu (0.110 mg/l), Pb (0.005 mg/l), Cd (0.001 mg/l) and Zn (0.191 mg/l) contents were also determined as shown in 'Table 1'. However elemental analysis of plant foliar material results indicated in 'Table 2' included C (58.0-47.5\%), O (31.3-39.0\%), N (12.7-6.5\%), P (0.33-0.5\%), S (0.32-0.15\%), Na (0.5-0.2\%), Ca (0.74-0.25\%), $\operatorname{Mg}(0.18-0.08 \%), \mathrm{K}(2.36-0.08 \%), \mathrm{Cl}(1.02-0.49 \%)$ and $\mathrm{Si}(0.32-0.13 \%)$.

\subsection{Germination attributes of Hordeum vulgare L.}

In the present study, the signs of germination showed a significant role of SBE in terms of resistance to salinity stress and maintaining good germination. The results (Table 3) indicated that TGI and CVE enhanced by pre-treating seed of barley with 30\% SBE under induced salinity stress while decrease in SBE alone without salinity 
stress. Similarly, GRI and $\mathrm{T}_{50 \%}$ indicated maximum gemination under 30\% SBE treatment whereas reduced in control condition. Consequently, GE and MET have been determined highest in $10 \%$ and $40 \%$ SBE treatment in the absence of salinity while decrease in $30 \%$ SBE pre-treated seeds of barley. On the whole, the results confirmed that concentration of $30 \%$ and $40 \%$ SBE used for the priming was found to be more useful in terms of G\% for the seeds exposed to salinity stress.

Table 1. Composition of SBE used as priming seed treatment under salinity stress.

\begin{tabular}{ll}
\hline Biochemical/Nutrients & Concentration \\
\hline Glycine betaine & $100 \mathrm{mmol} / \mathrm{kg} \mathrm{f} . \mathrm{wt}$ \\
Betalains & $1.36 \mathrm{mg} / \mathrm{l}$ \\
Phenolics & $1.30 \mathrm{~g} / 100 \mathrm{ml}$ \\
Flavonoids & $0.59 \mathrm{mg} / \mathrm{ml}$ \\
Carotenoids & $0.23 \mathrm{ml} / 100 \mathrm{ml}$ \\
Vitamin E & $0.002 \%$ \\
Vitamin C & $8.04 \mathrm{~g} / 100 \mathrm{ml}$ \\
Sugar & $8 \mathrm{~g} / 100 \mathrm{ml}$ \\
Protein & $1.39 \mathrm{mg} / 100 \mathrm{ml}$ \\
Oxalic acid & $38 \mathrm{mg} / 100 \mathrm{ml}$ \\
$\mathrm{pH}$ & 6.07 \\
$\mathrm{Cu}$ & $0.110 \mathrm{mg} / \mathrm{L}$ \\
$\mathrm{Pb}$ & $0.005 \mathrm{mg} / \mathrm{L}$ \\
$\mathrm{Cd}$ & $0.001 \mathrm{mg} / \mathrm{L}$ \\
$\mathrm{Zn}$ & $0.191 \mathrm{mg} / \mathrm{L}$ \\
$\mathrm{Na}$ & $3.098 \mathrm{mg} / \mathrm{L}$ \\
$\mathrm{Ca}$ & $13.72 \mathrm{mg} / \mathrm{L}$ \\
$\mathrm{K}$ & $11.45 \mathrm{mg} / \mathrm{L}$ \\
$\mathrm{Mg}$ & $7.121 \mathrm{mg} / \mathrm{L}$ \\
$\mathrm{Fe}$ & $1.501 \mathrm{mg} / \mathrm{L}$ \\
\hline
\end{tabular}

Table 2. Elemental analysis of plant tissue nutrients is analyzed by EDX under salinity stress.

\begin{tabular}{cccccccccccc}
\hline \multicolumn{10}{c}{ Elements/Weight\% } \\
\hline Treatment & $\mathbf{C}$ & $\mathbf{N}$ & $\mathbf{O}$ & $\mathbf{N a}$ & $\mathbf{M g}$ & $\mathbf{S i}$ & $\mathbf{P}$ & $\mathbf{S}$ & $\mathbf{C l}$ & $\mathbf{K}$ & $\mathbf{C a}$ \\
\hline T1 & 54.74 & 7.14 & 35.15 & 0.37 & 0.11 & 0.37 & 0.15 & 0.17 & 0.49 & 0.88 & 0.43 \\
T2 & 51.83 & 9.18 & 34.7 & 0.27 & 0.14 & 0.51 & 0.18 & 0.24 & 0.86 & 1.84 & 0.67 \\
T3 & 50.84 & 6.50 & 37.14 & 0.54 & 0.17 & 0.37 & 0.20 & 0.15 & 0.98 & 2.36 & 0.74 \\
T4 & 53.41 & 7.68 & 35.53 & - & - & 0.62 & 0.22 & 0.20 & 0.76 & 1.18 & 0.39 \\
T5 & 47.59 & 12.75 & 34.91 & 0.38 & - & 0.45 & 0.28 & 0.22 & 0.86 & 1.85 & 0.69 \\
T6 & 52.67 & 8.42 & 33.90 & 0.32 & 0.08 & 0.68 & 0.33 & 0.28 & 0.90 & 1.81 & 0.62 \\
T7 & 58.08 & - & 37.29 & 0.32 & - & 0.44 & 0.20 & 0.32 & 0.99 & 1.76 & 0.61 \\
T8 & 56.25 & - & 39.06 & 0.27 & 0.18 & 0.27 & 0.24 & 0.26 & 0.86 & 2.09 & 0.52 \\
T9 & 55.35 & 9.36 & 31.38 & 0.31 & 0.13 & 0.40 & 0.24 & 0.20 & 0.81 & 1.44 & 0.38 \\
T10 & 48.33 & 10.75 & 38.08 & 0.30 & - & 0.43 & - & 0.13 & 0.58 & 1.14 & 0.25 \\
T11 & 53.44 & 8.44 & 33.70 & 0.44 & 0.21 & 0.31 & 0.29 & 0.16 & 1.02 & 1.66 & 0.32 \\
\hline
\end{tabular}

T1=Control, T2=10\% SBE, T3=10\% SBE+40 mM NaCl, T4=20\% SBE, T5=20\% SBE+40 mM NaCl, T6=30\% $\mathrm{SBE}, \mathrm{T} 7=30 \% \mathrm{SBE}+40 \mathrm{mM} \mathrm{NaCl}, \mathrm{T} 8=40 \% \mathrm{SBE}, \mathrm{T} 9=40 \% \mathrm{SBE}+40 \mathrm{mM} \mathrm{NaCl}, \mathrm{T} 10=50 \% \mathrm{SBE}, \mathrm{T} 11=50 \%$ $\mathrm{SBE}+40 \mathrm{mM} \mathrm{NaCl}$. 
bioRxiv preprint doi: https://doi org/10.1101/2021.08.19.457015 this version posted August 19, 2021. The copyright holder for this preprint (which was not certified by peer review) is the author/funder, who has granted bioRxiv a license to display the preprint in perpetuity. It is made available under aCC-BY 4.0 International license.

Table 3. Effect of SBE on timson germination index (TGI), germination energy (GE), coefficient of uniformity of emergence (CUE), mean germination time (MGT), germination rate index (GRI) and time to 50\% emergence $(\mathrm{T} 50 \%)$ under induced salinity stress.

\begin{tabular}{ccccccc}
\hline Treatment & TGI & GE & CVE & MET & GRI & T50\% \\
\hline T1 & $1.5 \pm 0.06$ & $11.11 \pm 3.14$ & $202.47 \pm 10.55$ & $26.97 \pm 0.67$ & $6.53 \pm 0.15$ & $1.61 \pm 0.9$ \\
T2 & $3.3 \pm 0.11$ & $26.66 \pm 2.44$ & $351.94 \pm 15.83$ & $34.48 \pm 0.82$ & $9.75 \pm 0.36$ & $2.09 \pm 0.3$ \\
T3 & $3.1 \pm 0.04$ & $22.22 \pm 3.14$ & $331.32 \pm 14.04$ & $33.62 \pm 0.81$ & $9.31 \pm 0.36$ & $2.38 \pm 0.8$ \\
T4 & $2.0 \pm 0.24$ & $20.21 \pm 2.11$ & $281.52 \pm 44.95$ & $30.91 \pm 2.23$ & $8.51 \pm 0.17$ & $2.40 \pm 0.9$ \\
T5 & $1.9 \pm 0.19$ & $17.77 \pm 3.28$ & $280.10 \pm 28.90$ & $30.04 \pm 1.32$ & $8.35 \pm 0.76$ & $2.16 \pm 0.5$ \\
T6 & $1.6 \pm 0.43$ & $15.55 \pm 3.14$ & $208.34 \pm 97.14$ & $26.24 \pm 5.76$ & $6.94 \pm 0.73$ & $3.73 \pm 0.4$ \\
T7 & $3.7 \pm 0.12$ & $37.77 \pm 3.14$ & $421.33 \pm 25.26$ & $26.8 \pm 0.44$ & $11.33 \pm 0.47$ & $2.97 \pm 0.9$ \\
T8 & $1.8 \pm 0.17$ & $20.00 \pm 3.44$ & $252.35 \pm 15.94$ & $37.08 \pm 0.99$ & $8.08 \pm 0.65$ & $2.66 \pm 0.4$ \\
T9 & $1.9 \pm 0.14$ & $22.22 \pm 3.14$ & $253.59 \pm 34.13$ & $29.48 \pm 0.59$ & $8.35 \pm 0.58$ & $2.23 \pm 0.5$ \\
T10 & $1.1 \pm 0.11$ & $24.44 \pm 3.14$ & $327.36 \pm 25.42$ & $29.17 \pm 2.01$ & $9.31 \pm 0.44$ & $2.42 \pm 0.5$ \\
T11 & $2.9 \pm 0.22$ & $26.66 \pm 3.44$ & $262.36 \pm 30.89$ & $33.35 \pm 1.24$ & $8.55 \pm 0.84$ & $3.25 \pm 0.0$ \\
\hline
\end{tabular}

$\mathrm{T} 1=$ Control, $\mathrm{T} 2=10 \% \mathrm{SBE}, \mathrm{T} 3=10 \% \mathrm{SBE}+40 \mathrm{mM} \mathrm{NaCl}, \mathrm{T} 4=20 \% \mathrm{SBE}, \mathrm{T} 5=20 \% \mathrm{SBE}+40 \mathrm{mM} \mathrm{NaCl}, \mathrm{T} 6=30 \%$ SBE, $\mathrm{T} 7=30 \% \mathrm{SBE}+40 \mathrm{mM} \mathrm{NaCl}, \mathrm{T} 8=40 \% \mathrm{SBE}, \mathrm{T} 9=40 \% \mathrm{SBE}+40 \mathrm{mM} \mathrm{NaCl}, \mathrm{T} 10=50 \% \mathrm{SBE}, \mathrm{T} 11=50 \%$ $\mathrm{SBE}+40 \mathrm{mM} \mathrm{NaCl}$.

\subsection{Physiological and biochemical attributes}

It is suggested that the degradation of plant chlorophyll content and increase in cellular respiration rate under stress condition is related with the accumulation of reactive oxygen species (Camejo et al. 2006). Plant foliar material was analyzed for photosynthetic pigments such as chlorophyll a/b ratio, total Chlorophyll and carotenoid content were significantly enhanced by increasing concentration from $20-40 \%$ SBE under salinity stress. According to (Fig. 1-3) results revealed that maximum values of chlorophyll a/b ratio, total chlorophyll content and carotenoid contents were recorded in T5, T10, and T6 while minimum results have been obtained by applying the extract without salinity indicated that SBE is a natural bio-stimulant as well as creating plant ability to stress tolerance by activating different physiological processes respectively. Furthermore, the results showed that there is a big difference among all the primed and non-primed treatments under induced salinity stress (40 $\mathrm{mM} \mathrm{NaCl})$.

Plants perceive a change in their physiological events in response to several abiotic stress and therefore respond shortly by accumulating different protective osmolytes mostly comprising sugar, proline and glycine betaine to provide favorable environment for metabolic activities and also protecting the plant by reducing the harmful damages caused by oxidative stress (Hayat et al. 2012). Similarly, plant osmolyte such as soluble sugar content has been recorded maximum in T11 followed by T9 under induced salinity stress in (Fig. 4). Results revealed that primed seeds have a great influenced on the soluble sugar content up to a significant level. Therefore, 
it is investigated that increasing the SBE concentration, sugar content will also be enhanced under salinity. Consequently, soluble protein content (Fig. 5) was measured maximum in $\mathrm{T} 11(50 \% \mathrm{SBE})$ up to significant level $(\mathrm{p}<0.05)$ under induced salinity stress revealed that the soluble protein content has been promoted by increasing the concentrations of SBE. Nonetheless, total proline content (Fig. 6) of leaf was recorded highest in T11 by increasing SBE concentrations under induced salinity stress.

Formation of reactive oxygen species neutralize by various antioxidant enzymes by protecting the plants from harmful oxidative damage in stress environment is particularly unpredictable mechanism among different plant species and different cultivars of the same species (Hayat et al. 2012). The priming of seeds with different concentrations of SBE effectively reduced these enzymes activities by increasing sugar beet concentrations. Regarding SOD activity, 20\% SBE concentrations are significantly more effective at improving SOD activity under salinity stress than other SBE levels (Fig. 7). However, in terms of POD activity, this improvement was greater in plants grown with 30\% SBE primed under induced stress conditions (Fig. 8). Similarly, hydrogen peroxide activity studied in 'Figure 9' has been reported maximum in 30\% sugar beet extract followed by $50 \%$ SBE. MDA is marker of lipid peroxidation/membrane loss under stress and indicates plant resistance to stress. In the current study, the MDA concentration augmented significantly enhanced under salinity in T11 stress as compared to plants grown under control and without salinity (Fig. 10).

\subsection{Regression and correlation analysis of the measured traits}

Statistical analysis showed that sugar beet extract affected on hydrogen peroxide activity in crop plants. Analysis of variance of measured traits with significant differences between treatments and within treatments was carried out between the priming factors under Salinity Stress (Table 4).

According to the results of (Table 5,6), regression and correlation analysis showed a significant positive correlation ( $\mathrm{p} \leq 0.05)$ between total chlorophyll and carotenoids content. Similarly, a positive correlation was also found between SSC, SOD, POD and MDA content in the leaves at $\mathrm{p}<0.05$. 
Table 4. Analysis of variance of measured traits under salinity stress in Hordeum vulgare L.

\begin{tabular}{|c|c|c|c|c|c|c|}
\hline Traits & Source of variation & SS & Df & MS & $\mathbf{F}$ & $\mathbf{P}$ \\
\hline \multirow[t]{3}{*}{ Chlo a/b ratio } & Between treatments & 68.647 & 10 & 6.865 & 0.771 & 0.655 \\
\hline & Within treatments & 195.985 & 22 & 8.908 & - & - \\
\hline & Error & 264.633 & 32 & - & - & - \\
\hline \multirow[t]{3}{*}{ TCC } & Between treatments & 6.948 & 10 & 0.695 & 2.350 & $0.046^{*}$ \\
\hline & Within treatments & 6.505 & 22 & 0.296 & - & - \\
\hline & Error & 13.453 & 32 & - & - & - \\
\hline \multirow[t]{3}{*}{$\mathrm{CC}$} & Between treatments & 5.529 & 10 & 0.553 & 2.956 & $0.016^{*}$ \\
\hline & Within treatments & 4.115 & 22 & 0.187 & - & - \\
\hline & Error & 9.644 & 32 & - & - & - \\
\hline \multirow[t]{3}{*}{ SSC } & Between treatments & 0.742 & 10 & 0.074 & 4.855 & $0.001 * *$ \\
\hline & Within treatments & 0.336 & 22 & 0.015 & - & - \\
\hline & Error & 1.078 & 32 & & - & - \\
\hline \multirow[t]{3}{*}{ SPC } & Between treatments & 5.318 & 10 & 0.532 & 3.126 & $0.012 *$ \\
\hline & Within treatments & 3.743 & 22 & 0.170 & - & - \\
\hline & Error & 9.062 & 32 & - & - & - \\
\hline \multirow[t]{3}{*}{ TPC } & Between treatments & 5.450 & 10 & 0.545 & 3.872 & $0.004 *$ \\
\hline & Within treatments & 3.097 & 22 & 0.141 & - & - \\
\hline & Error & 8.547 & 32 & - & - & - \\
\hline \multirow[t]{3}{*}{ POD } & Between treatments & 1.662 & 10 & 0.166 & 0.851 & 0.588 \\
\hline & Within treatments & 4.296 & 22 & 0.195 & - & - \\
\hline & Error & 5.959 & 32 & - & - & - \\
\hline \multirow[t]{3}{*}{ SOD } & Between treatments & 0.231 & 10 & 0.023 & 11.522 & $0.000 * * *$ \\
\hline & Within treatments & 0.044 & 22 & 0.002 & - & - \\
\hline & Error & 0.275 & 32 & - & - & - \\
\hline \multirow[t]{3}{*}{$\mathbf{H}_{2} \mathbf{O}_{2}$} & Between treatments & 4.493 & 10 & 0.449 & 1.494 & 0.207 \\
\hline & Within treatments & 6.615 & 22 & 0.301 & - & - \\
\hline & Error & 11.108 & 32 & - & - & - \\
\hline \multirow[t]{3}{*}{ MDA } & Between treatments & 0.011 & 10 & 0.001 & 2.455 & $0.038^{*}$ \\
\hline & Within treatments & 0.010 & 22 & 0.000 & - & - \\
\hline & Error & 0.022 & 32 & - & - & - \\
\hline
\end{tabular}

Chlo a/b ratio=chlorophyll a/b ratio, $\mathrm{TCC}=$ total chlorophyll content, $\mathrm{CC}=$ caroteniod content, $\mathrm{SCC}=$ soluble sugar content, $\mathrm{SPC}=$ soluble protein content, $\mathrm{TPC}=$ total proline content, $\mathrm{POD}=$ peroxidase content, $\mathrm{SOD}=$ superoxide dismutase content, $\mathrm{H}_{2} \mathrm{O}_{2}=$ hydrogen peroxide, $\mathrm{MDA}=$ malendyaldehyde, $*$ is significant up to $\mathrm{p}=0.01, * *$ is significant to $\mathrm{p}=0.01, * * *$ is significant up to $\mathrm{p}=0.001$. 
Table 5. Regression and correlation analysis between physiological and biochemical parameter in Hordeum vulgare L. under induced salinity stress.

\begin{tabular}{ccccccccccc}
\hline Chlo a/b & TCC & CC & SSC & SPC & TPC & POD & SOD & H $_{2}$ & MDA \\
\hline $\mathrm{R}=0.034^{\mathrm{a}}$ & $\mathrm{R}=0.269^{\mathrm{a}}$ & $\mathrm{R}=0.211^{\mathrm{a}}$ & $\mathrm{R}=0.460^{\mathrm{a}}$ & $\mathrm{R}=0.701^{\mathrm{a}}$ & $\mathrm{R}=0.250^{\mathrm{a}}$ & $\mathrm{R}=0.122^{\mathrm{a}}$ & $\mathrm{R}=0.653^{\mathrm{a}}$ & $\mathrm{R}=0.090 \mathrm{a}$ & $\mathrm{R}=0.199 \mathrm{a}$ \\
$\mathrm{R}^{2}=0.001$ & $\mathrm{R}^{2}=0.068$ & $\mathrm{R}^{2}=0.044$ & $\mathrm{R}^{2}=0.211$ & $\mathrm{R}^{2}=0.491$ & $\mathrm{R}^{2}=0.063$ & $\mathrm{R}^{2}=0.015$ & $\mathrm{R}^{2}=0.427$ & $\mathrm{R}^{2}=0.008$ & $\mathrm{R}^{2}=0.040$ \\
\hline Chlo a/b & TCC & $\mathbf{C C}$ & $\mathbf{S S C}$ & $\mathbf{S P C}$ & $\mathbf{T P C}$ & POD & SOD & $\mathbf{H}_{2} \mathbf{O}_{2}$ & MDA \\
\hline $\mathrm{R}=0.098$ & $\mathrm{R}=0.167$ & $\mathrm{R}=0.299^{\mathrm{a}}$ & $\mathrm{R}=0.055^{\mathrm{a}}$ & $\mathrm{R}=0.649^{\mathrm{a}}$ & $\mathrm{R}=0.450^{\mathrm{a}}$ & $\mathrm{R}=0.505^{\mathrm{a}}$ & $\mathrm{R}=0.461^{\mathrm{a}}$ & $\mathrm{R}=0.104^{\mathrm{a}}$ & $\mathrm{R}=0.058^{\mathrm{a}}$ \\
$\mathrm{R}^{2}=0.010$ & $\mathrm{R}^{2}=0.174$ & $\mathrm{R}^{2}=0.090$ & $\mathrm{R}^{2}=0.003$ & $\mathrm{R}^{2}=0.421$ & $\mathrm{R}^{2}=0.065$ & $\mathrm{R}^{2}=0.203$ & $\mathrm{R}^{2}=0.213$ & $\mathrm{R}^{2}=0.011$ & $\mathrm{R}^{2}=0.003$ \\
\hline
\end{tabular}

Chlo a/b ratio=chlorophyll a/b ratio, $\mathrm{TCC}=$ total chlorophyll content, $\mathrm{CC}=$ caroteniod content, $\mathrm{SCC}=$ soluble sugar content, $\mathrm{SPC}=$ soluble protein content, $\mathrm{TPC}=$ total proline content, $\mathrm{POD}=$ peroxidase content, $\mathrm{SOD}=$ superoxide dismutase content, $\mathrm{H}_{2} \mathrm{O}_{2}=$ hydrogen peroxide, $\mathrm{MDA}=$ malendyaldehyde, $*$ is significant up to $\mathrm{p}=0.01, * *$ is significant to $\mathrm{p}=0.01, * * *$ is significant up to $\mathrm{p}=0.001$.

Table 6. Multicorrelation Analysis of Physiological and Biochemical Components in Hordeum vulgare L. nder induced salinity stress.

\begin{tabular}{|c|c|c|c|c|c|c|c|c|c|c|}
\hline Traits & Chlo a/b ratio & TCC & $\mathrm{CC}$ & SSC & SPC & TPC & POD & SOD & $\mathrm{H}_{2} \mathrm{O}_{2}$ & MDA \\
\hline Chlo a/b ratio & 1.0 & & & & & & & & & \\
\hline TCC & 0.286 & 1.0 & & & & & & & & \\
\hline $\mathrm{CC}$ & 0.054 & 0.005 & 1.0 & & & & & & & \\
\hline SSC & 0.177 & 0.173 & 0.040 & 1.0 & & & & & & \\
\hline SPC & 0.004 & 0.034 & 0.036 & $0.489^{* *}$ & 1.0 & & & & & \\
\hline TPC & 0.006 & 0.019 & 0.020 & 0.186 & 0.301 & 1.0 & & & & \\
\hline POD & 0.096 & 0.291 & 0.089 & 0.037 & 0.102 & $0.416^{*}$ & 1.0 & & & \\
\hline SOD & 0.144 & $0.469^{* *}$ & 0.074 & 0.309 & $0.406^{*}$ & 0.147 & 0.070 & 1.0 & & \\
\hline $\mathrm{H}_{2} \mathrm{O}_{2}$ & 0.142 & 0.110 & 0.278 & 0.240 & 0.153 & 0.180 & 0.137 & 0.095 & 1.0 & \\
\hline MDA & 0.053 & -0.293 & 0.132 & 0.116 & 0.011 & 0.122 & 0.071 & $0.412^{*}$ & 0.196 & 1.0 \\
\hline
\end{tabular}

Chlo $\mathrm{a} / \mathrm{b}$ ratio $=$ chlorophyll $\mathrm{a} / \mathrm{b}$ ratio, $\mathrm{TCC}=$ total chlorophyll content, $\mathrm{CC}=$ caroteniod content, SCC=soluble sugar content,

$\mathrm{SPC}=$ soluble protein content, $\mathrm{TPC}=$ total proline content, $\mathrm{POD}=$ peroxidase content, $\mathrm{SOD}=$ superoxide dismutase content,

$\mathrm{H}_{2} \mathrm{O}_{2}=$ hydrogen peroxide, $\mathrm{MDA}=$ malendyaldehyde. 


\subsection{Principle component analysis of biological component}

Principle component analysis were studied on 10 characters (Table 7) enclosed over all $55.009 \%$ of the whole variation. The PC1 explained $23.562 \%$ of complete variance which were significantly correlate with protein, proline, soluble sugar content and carotenoid content particularly related with osmolytes. while PC2 investigated $17.694 \%$ of complete variance which was particularly correlate with total chlorophyll content, chlorophyll "a/b" ratio, SOD and POD corresponded to plant antioxidant enzymes and growth components.

Table 7. Principal component based on correlation matrix of biological component in Hordeum vulgare L.

\begin{tabular}{ccccccc}
\hline Components & Eigen value & Individual & Cumulative & PC1 & PC2 & PC3 \\
\hline Chlo a/b ratio & 1.788 & 13.753 & 55.009 & 0.337 & 0.249 & 0.496 \\
TC & 1.306 & 10.050 & 65.059 & 0.921 & 0.235 & 0.140 \\
CC & 1.111 & 8.547 & 73.605 & 0.080 & 0.102 & 0.425 \\
SSC & 1.000 & 7.690 & 81.296 & 0.313 & 0.596 & 0.390 \\
SPC & 0.725 & 5.574 & 86.870 & 0.280 & 0.742 & 0.055 \\
TPC & 0.582 & 4.480 & 91.350 & 0.067 & 0.563 & 0.282 \\
POD & 0.460 & 3.537 & 94.887 & 0.192 & 0.396 & 0.612 \\
SOD & 0.330 & 2.535 & 97.422 & 0.733 & 0.337 & 0.125 \\
H2 & 0.203 & 1.565 & 98.987 & 0.158 & 0.164 & 0.640 \\
MDA & 0.132 & 1.013 & 100.000 & 0.422 & 0.283 & 0.236 \\
\hline
\end{tabular}

Chlo $\mathrm{a} / \mathrm{b}$ ratio $=$ chlorophyll $\mathrm{a} / \mathrm{b}$ ratio, $\mathrm{TCC}=$ total chlorophyll content, $\mathrm{CC}=$ caroteniod content, $\mathrm{SCC}=$ soluble sugar content, $\mathrm{SPC}=$ soluble protein content, $\mathrm{TPC}=$ total proline content, $\mathrm{POD}=$ peroxidase content, $\mathrm{SOD}=$ superoxide dismutase content, $\mathrm{H}_{2} \mathrm{O}_{2}=$ hydrogen peroxide, $\mathrm{MDA}=$ malendyaldehyde.

\section{Discussion}

Irrespective of hundreds of factors causing impediments in plant growth and development, water shortage is reckoned as a main abiotic factor that affects the crop growth and limits the global food production (Noman et al. 2018). Sugar beet extract is a vital supply of flavonoids, glycine betaine, betalains, phenolics, ascorbic acid (AsA) etc. and is found to be most effective as a bio-stimulant described by the ECBI (European Council of Bio-stimulant Industry) (Colla et al. 2015; Nyoni et al. 2020). The current study revealed that priming with SBE enhanced germination energy (GE), means germination time (MGT), coefficient of velocity of emergence (CVE) as compared to control. Our results are 
according to the findings of Noman et al. (2020) who reported significant enhancement in GE, MET and CVE by priming seeds with SBE under water stressed wheat. Among the treatments of 10\% SBE and 30\% SBE are more effective to salinity stress. This suggested that sugar beet extract could be better treatment of seed priming for crops (Ansari and Zede 2012). Similarly, salt stress limited the levels of C, N and O in barley leaves. It has been suggested that pre-sowing seed treatment with concentrated SBE endeavored to balance the reduced minerals in plants under salinity stress as well as germination parameters. (Abbas et al. 2010; Liu et al. 2020).

Differences in photosynthetic pigments are a key indicator for determining the photosynthetic pigments of plants under salinity stress. Our results (Fig. 1-3) showed a noticeable increase in chlorophyll "a/b ratio, total chlorophyll and carotenoids by pre-sowing seeds with SBE both with and without salinity stress. Our findings are correlated with the study of Du-Jardin (2015), Ali and Ashraf (2011) who suggested that SBE act as a natural biostimulant against salinity stress. However, carotenoids content increased under salinity due to SBE seed priming might have a defensive role by reducing the damages to photosystem II proteins due to reduced light harvesting.

The osmolytes in leaf such as sugar and proline level by priming with SBE were measured highest under induces salinity stress that proved to be effective by the adverse effect of stress condition in barley. Similar results have been found by Abbas et al. (2010) who studied that proline concentration in the leaves of both eggplant cultivars increased markedly with salt treatment. Furthermore, it is estimated that different concentrations of sugar beet extract enhanced the proline contents under induced salinity stress, respectively (Abdelaal et al. 2020; Zeeshan et al. 2020). Similarly increase in soluble protein under salinity stress via seed priming with 50\% SBE may be due to broadspectrum of stress resistance that has been unlocked by osmolytes to survive under several biotic and abiotic stresses. Our results are corelated with the finding of Noman et el. (2018) who studied that SBE seed pre-sowing further improved the total protein content of plants grown under both control and stressed conditions.

To reduce the negative effects of ROS, plants have well-developed antioxidant defense mechanisms that include the activity of well-known antioxidant enzymes including CAT, POD, SOD, and APX (Zeeshan et al. 2020). Antioxidant enzymes such as POD, SOD, MDA activities enhanced by pre-sowing seeds with SBE while $\mathrm{H}_{2} \mathrm{O}_{2}$ formation was maximum under applied salinity stress. Increased activity of SOD indicates the efficient destruction of superoxide ion to $\mathrm{H}_{2} \mathrm{O}_{2}$ which is eliminated by POD (Mollern 2007) whereas, GB (glycine betaine) present in SBE enhanced osmoprotectant level which reduce ROS formation by acting as antioxidative compound (Jamil et al. 2015). 
Similar results have been indicated by Ebrahim et al. (2020) who reported that the sugar beet extract was significant under the induced salinity stress.

\section{Conclusion}

The present study investigated that seed priming with SBE is a reliable and cost-effective technique for the agricultural and seed quality. It can be evaluated that seed priming treatment with sugar beet extract is of significant value for barley plants facing osmotic stress. A clear correspondence between modulated concentrations of mineral ions, antioxidative enzymes and germination indices was measured in barley plants elevated from seeds treated with SBE under salinity stress. Overall, 30, 40 and 50\% concentration SBE exerted a positive effect on germination, physiobiochemical under both untreated primed as well as saline treated stressed condition. Nevertheless, further research on SBE will be useful for seed quality and germination parameters as still there is a demand for additional exploration of plant stress tolerance mechanism by priming seeds with SBE through involving modeling and experimental approaches. Forthcoming findings would be performed utilizing varied cultivars/lines for drawing parallels among SBE application under field conditions, salinity stress, ionic mobility patterns, crop quality and production.

\section{Acknowledgements}

We are highly acknowledged to Department of Botany, University of Peshawar for providing all facilities regarding this work.

\section{Data Availability}

Data associated with the present paper can be obtained by contacting the corresponding authors.

\section{Conflict of Interests}

All the authors declare that they have no conflict of interest.

\section{Funding}

No funding was given by any source to conduct this study. However, this study is a part of M.Phil degree of first author for which Botany Department, University of Peshawar, Pakistan provided the laboratory facilities. 


\section{Authors' contributions}

Sami Ullah designed the experiments and supervised the experiments of the first author Noor Ali Shah who conducted the experiments, wrote manuscript and analysed all data. Sajjad Ali, Muhammad Adnan and Muhammad Nauman Khan conduct antioxidants and biochemical analysis, Amjad Ali, Ajmal Khan and Said Hassan did statistical analysis and help in manuscript writing, Muhammad Ali and Wisal Muhammad Khan reviewed and checked the final version. All authors have read and agreed to its contents and also that the manuscript complies with the policy of the publication.

\section{References}

1. Abbas W, Ashraf M., Akram N A (2010) Alleviation of salt-induced adverse effects in eggplant (Solanum melongena L.) by glycine betaine and sugar beet extracts. Sci hortic 125(3): 188-195.

2. Abdelaal K A, Attia K A, Alamery S F, El-Afry M M, Ghazy A I, Tantawy D S, Hafez Y M (2020) Exogenous application of proline and salicylic acid can mitigate the injurious impacts of drought stress on barley plants associated with physiological and histological characters. Sustainability 12(5): 1736.

3. AbdElgawad H, Zinta G, Hegab M M, Pandey R, Asard H, Abuelsoud W (2016) High salinity induces different oxidative stress and antioxidant responses in maize seedlings organs. Front Plant Sci 7:276.

4. Ahanger M A, Mir R A, Alyemeni M N, Ahmad P (2020) Combined effects of brassinosteroid and kinetin mitigates salinity stress in tomato through the modulation of antioxidant and osmolyte metabolism. Plant Physiol Biochem 147: 31-42

5. Ahmad S, Cui W, Kamran M, Ahmad I, Meng X, Wu X, Han Q (2020 Exogenous application of melatonin induces tolerance to salt stress by improving the photosynthetic efficiency and antioxidant defense system of maize seedling. J Plant Growth Reg 1-14.

6. Ali A Y A, Ibrahim M E H, Zhou G, Nimir N E A, Jiao X, Zhu G, Yue W (2020) Exogenous jasmonic acid and humic acid increased salinity tolerance of sorghum. Agron. J 112(2): 871-884

7. Ali Q, Ashraf M (2011) Induction of Drought Tolerance in Maize (Zea mays L.) due to Exogenous Application of Trehalose: Growth, Photosynthesis, Water Relations and Oxidative Defense Mechanism. J agro Crop sci 197(4): 258-271. 
8. Ali Z, Ashraf M, Ashraf M Y, Anwar S U, Ahmad K (2020) Physiological response of different accessions of Sesbania sesban and Cyamopsis tetragonoloba under water deficit conditions. Pak J Bot 52(2): 395-404.

9. Allel D, Ben-Amar A, Badri M, Abdelly C (2016) Salt tolerance in barley originating from harsh environment of North Africa. Aust J Crop Sci 10(04): 438-451.

10. Ansari O, Zadeh F S (2012) Osmo and hydro priming mediated germination improvement under cold stress conditions in mountain rye (Secale montanum). Cercet Agron Mold 45(3): 53-62

11. Arnon D I (1949) Copper enzymes in isolated chloroplasts. Polyphenoloxidase in Beta vulgaris. Plant Physiol 24(1) 1-15.

12. Asthir B, Kaur S, Mann S K (2009) Effect of salicylic and abscisic acid administered through detached tillers on antioxidant system in developing wheat grains under heat stress. Acta Physiologiae Plantarum 31 (5): 1091-96.

13. Backer H, Frank O, De-Angells B, Feingold S (1980) Plasma tocopherol in man at various times after ingesting free or acetylated tocopherol. Nut Rep Int 21: 531-536

14. Bushra S, Farooq A, Muhammad A (2009) Effect of extraction solvent/technique on the antioxidant activity of selected medicinal plant extracts. Molecules 14(6): 2167-2180

15. Camejo D, Jiménez A, Alarcón J J, Torres W, Gómez J M, Sevilla F. (2006) Changes in photosynthetic parameters and antioxidant activities following heat-shock treatment in tomato plants. Functional Plant Biology 33: 177-187.

16. Cai Y Z, Sun M, Corke H (2005) Characterization and application of betalain pigments from plants of the Amaranthaceae. Trends Food Sci Technol 16(9): 370-376.

17. Colla G, Rouphael Y, Di-Mattia E, El-Nakhel C, Cardarelli M. (2015) Co-inoculation of Glomus intraradices and Trichoderma atroviride acts as a bio-stimulant to promote growth, yield and nutrient uptake of vegetable crops. J Sci Food Agric 95(8): 1706-1715.

18. Coolbear P, Francis A, Grierson D (1984) The effect of low temperature pre-sowing treatment on the germination performance and membrane integrity of artificially aged tomato seeds. J Exp Bot 35(11): 1609-1617.

19. Dubois M, Gilles K A, Hamilton J K, Rebers P T, Smith F (1956) Colorimetric method for determination of sugars and related substances. Analytical chemistry 28: 350-356.

20. Du-Jardin P (2015) Plant biostimulants: Definition, concept, main categories and regulation Sci Hort 196: 3-14.

21. Ebrahim F, Arzani A, Rahimmalek M, Sun D, Peng J (2020) Salinity tolerance of wild barley Hordeum vulgare specie spontaneum. Plant Breed. 139(2): 304-316. 
22. Fedoroff N V, Battisti D S, Beachy R N, Cooper P J, Fischhoff D A, Hodges C N, Zhu J K (2010) Radically rethinking agriculture for the 21st century. Sci 327(5967): 833-834.

23. Gorin N, Heidema F T (1976) Peroxidase activity in Golden Delicious apples as a possible parameter of ripening and senescence. J agric food chem 24(1): 200-201.

24. Gorzolka K, Kölling J, Nattkemper T W, Niehaus K (2016) Spatio-temporal metabolite profiling of the barley germination process by MALDI MS imaging. PLOS ONE 11(3): 1-25.

25. Grieve C M, Grattan S R (1983) Rapid assay for determination of water-soluble quaternary ammonium compounds. Plant Soil 70(2): 303-307.

26. Hawrylak-Nowak B, Hasanuzzaman M, Wójcik M (2019) Bio-stimulation and biofortification of crop plantsnew challenges for modern agriculture. Acta Agro Bot 72(2): 1777.

27. Hayat S, Hayat Q, Alyemeni M N, Wani A S, Pichtel J, Ahmad A (2012) Role of proline under changing environments: a review. Plant signaling \& behavior 7: 1456-1466.

28. Jackson M, Miller R, Forkiln R (1973) Soil chemical analysis Prentic-Hall of India Pvt. \& Ltd. New Delhi: 2nd Indian Rep.

29. Jamil S, Ali Q, Iqbal M, Iftikhar W, Shahzad F, Javed M T, Perveen R (2015) Modulations in plant water relations and tissue specific osmoregulation by foliar-applied ascorbic acid and the induction of salt tolerance in maize plants. Braz J Bot 38(3): 527-538.

30. Javed, H., Riaz, A., Qureshi, A., Javed, K., Mujeeb, F., Ijaz, F., Aftab, M. (2020): Isolation, characterization and screening of PGPR capable of providing relief in salinity stress. Eurasian J. Soil Sci. 9(2), 85-91.

31. Kashif M, Arshad M, Cheema J M, Waraich E A (2020) Modeling root zone salinity dynamics using integrated effect of soil, water, crop and climate for semi-arid region. Pak J Agric Sci 57(3): 1-16.

32. Kaydan D, Yagmur M (2008) Germination, seedling growth and relative water content of shoot in different seed sizes of triticale under osmotic stress of water and NaCl. Afr J Biotechnol 7(16): 2862-2868.

33. Keeney D R, Nelson D W (1983) Nitrogen-Inorganic Forms. In Methods of Soil Analysis. 643-698

34. Liu C, Zhao X, Yan J, Yuan Z, Gu M (2020) Effects of salt stress on growth, photosynthesis, and mineral nutrients of 18 pomegranate (Punica granatum) Cultivars. Agron 10(1): 1-27. 
35. Mahdy A M, Sherif F K, Elkhatib E A, Fathi N O, Ahmed M H (2020) Seed priming in nanoparticles of water treatment residual can increase the germination and growth of cucumber seedling under salinity stress. J Plant Nutr 43(12): 1862-1874

36. Mohdaly A A, Sarhan M A, Smetanska I, Mahmoud A (2010) Antioxidant properties of various solvent extracts of potato peel, sugar beet pulp and sesame cake. J Sci Food Agri 90(2): 218-226.

37. Mollern I M, Jensen P E, Hansson A (2007) Oxidative modifications to cellular components in plants. Ann Rev Plant Biol 58: 459-481.

38. Mukherjee S P, Choudhuri M A (1983) Implications of water stress-induced changes in the levels of endogenous ascorbic acid and hydrogen peroxide in Vigna seedlings. Physiol Plant 58(2): 166-170

39. Narimani T, Toorchi M, Tarinejad A R, Mohammadi S A, Mohammadi H (2020) Physiological and Biochemical Evaluation of Barley (Hordeum vulgare L.) under Salinity Stress. J Agric Sci Technol 22(4): 1009-1021

40. Nasri S, Mandoulakani B A, Darvishzadeh R, Bernousi I (2013) Retrotransposon insertional polymorphism in Iranian bread wheat cultivars and breeding lines revealed by IRAP and REMAP markers. Biochem Genet 51(11): 927-943.

41. Nelson D W, Sommers L E (1983) Total Carbon, Organic Carbon, and Organic Matter. In Methods of Soil Analysis. 539-579

42. Nelson L, Heidel H (1952) Soil analysis methods as used in the Iowa State College Soil Testing Laboratory.

43. Nilsson T (1970) Studies into the pigments in beetroot (Beta vulgaris L. ssp. Vulgaris var. Rubra L.). Antbrukshõgskolans Annaler 36: 179-219.

44. Noman A, Ali Q, Naseem J, Javed M T, Kanwal H, Islam W, Aqeel M, Khalid K, Zafar S, Tayyeb M, Iqbal N, Buriro M, Maqsood J, Shahid S (2018) Sugar beet extract acts as a natural bio-stimulant for physio-biochemical attributes in water stressed wheat (Triticum aestivum L.). Acta Physiologia Plantarum 40(110): 1-14.

45. Nyoni N, Ndlovu E, Maphosa M (2020) Effect of priming regimes on seed germination of field crops. Afri Crop Sci J 28(2): 169-176

46. Pinheiro C L, Araújo H T N, De-Brito S F, Da-Silva M M, Da-Silva V J, Medeiros F S (2018) Seed priming and tolerance to salt and water stress in divergent grain sorghum genotypes. Ameri J Plant Sci 9(4): 606-616.

47. Sanders D (2020) The salinity challenge. New Phytol 225(3): 1047-1048. 
48. Sarwar Y, Shahbaz M (2020) Modulation in growth, photosynthetic pigments, gas exchange attributes and inorganic ions in sunflower (Helianthus annuиs L.) By strigolactones (gr24) achene priming under saline conditions. Pak J Bot 52(1): 23-31.

49. Vetter J L, Steinberg M P, Nelson A I (1958) Enzyme assay, quantitative determination of peroxidase in sweet corn. J agri food chem 6(1) 39-41.

50. Velikova V, Yordanov I, Edreva A (2000) Oxidative stress and some antioxidant systems in acid rain-treated bean plants: protective role of exogenous polyamines. Plant science 151: 59-66

51. Waterhouse A L (2002) Determination of total phenolics. CPFAC. 6(1): 1-7.

52. Zeeshan M, Lu M, Sehar S, Holford P, Wu F (2020) Comparison of biochemical, anatomical, morphological, and physiological responses to salinity stress in wheat and barley genotypes deferring in salinity tolerance. Agron 10(1): 127.

53. Zhu M, Kong F, Li Y, Li M, Zhang J, Xi M (2020) Effects of moisture and salinity on soil dissolved organic

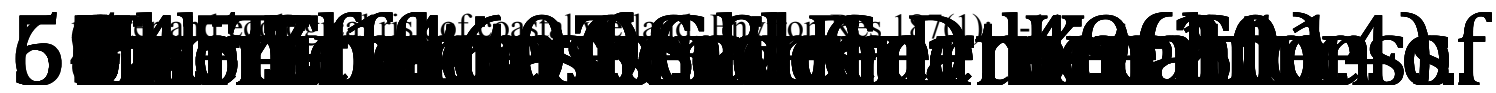

62. Zhang Q, Rue K (2014) The Effect of Glycine betaine Priming on Seed Germination of Six Turfgrass Species under Drought, Salinity, or Temperature Stress. Horticulture Science 49(11): 1454-1460.

\section{Figure legends}

Figure 1. Effect of sugar beet extract on chlorophyll "a/b" ratio under induced salinity stress. Vertical bars represent SE.

Figure 2. Effect of sugar beet extract on total chlorophyll contents under induced salinity stress. Vertical bars represent SE.

Figure 3. Effect of sugar beet extract on carotenoid content under induced salinity stress. Vertical bars represent SE.

Figure 4. Effect of sugar beet extract on soluble sugar content under induced salinity stress. Vertical bars represent SE.

Figure 5. Effect of sugar beet extract on soluble protein content under induced salinity stress. Vertical bars represent SE.

Figure 6. Effect of sugar beet extract on total proline contents under induced salinity stress. Vertical bars represent SE.

Figure 7. Effect of sugar beet extract on superoxide dismutase under induced salinity stress. Vertical bars represent SE.

Figure 8. Effect of sugar beet extract on peroxidase under induced salinity stress. Vertical bars represent SE.

Figure 9. Effect of sugar beet extract on hydrogen peroxide under induced salinity stress. Vertical bars represent SE. 
Figure 10. Effect of sugar beet extract on MDA content under induced salinity stress. Vertical bars represent SE. 


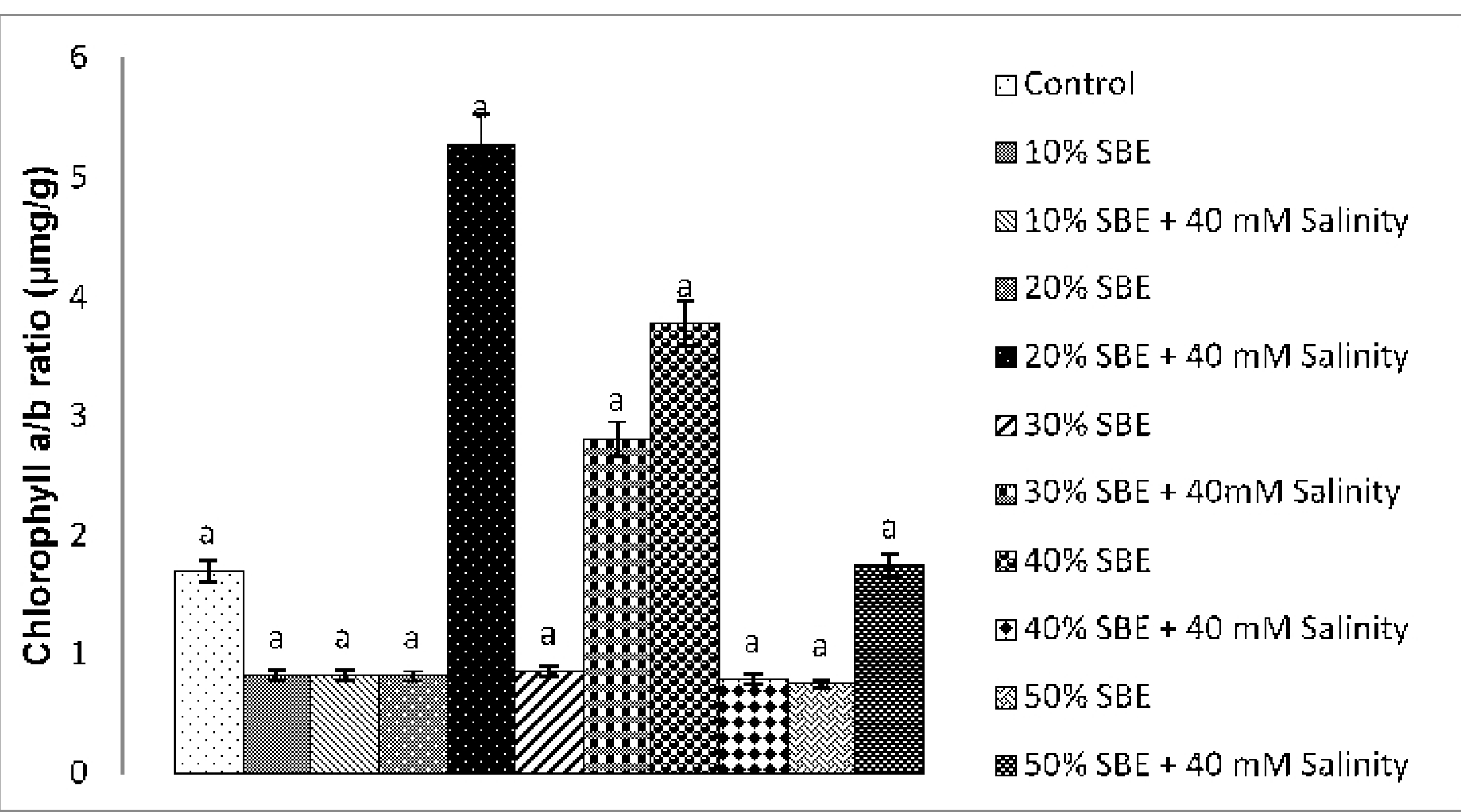

Figure 1. Effect of sugar beet extract on chlorophyll "a/b" ratio under induced salinity stress. Vertical bars represent SE.

Figure 


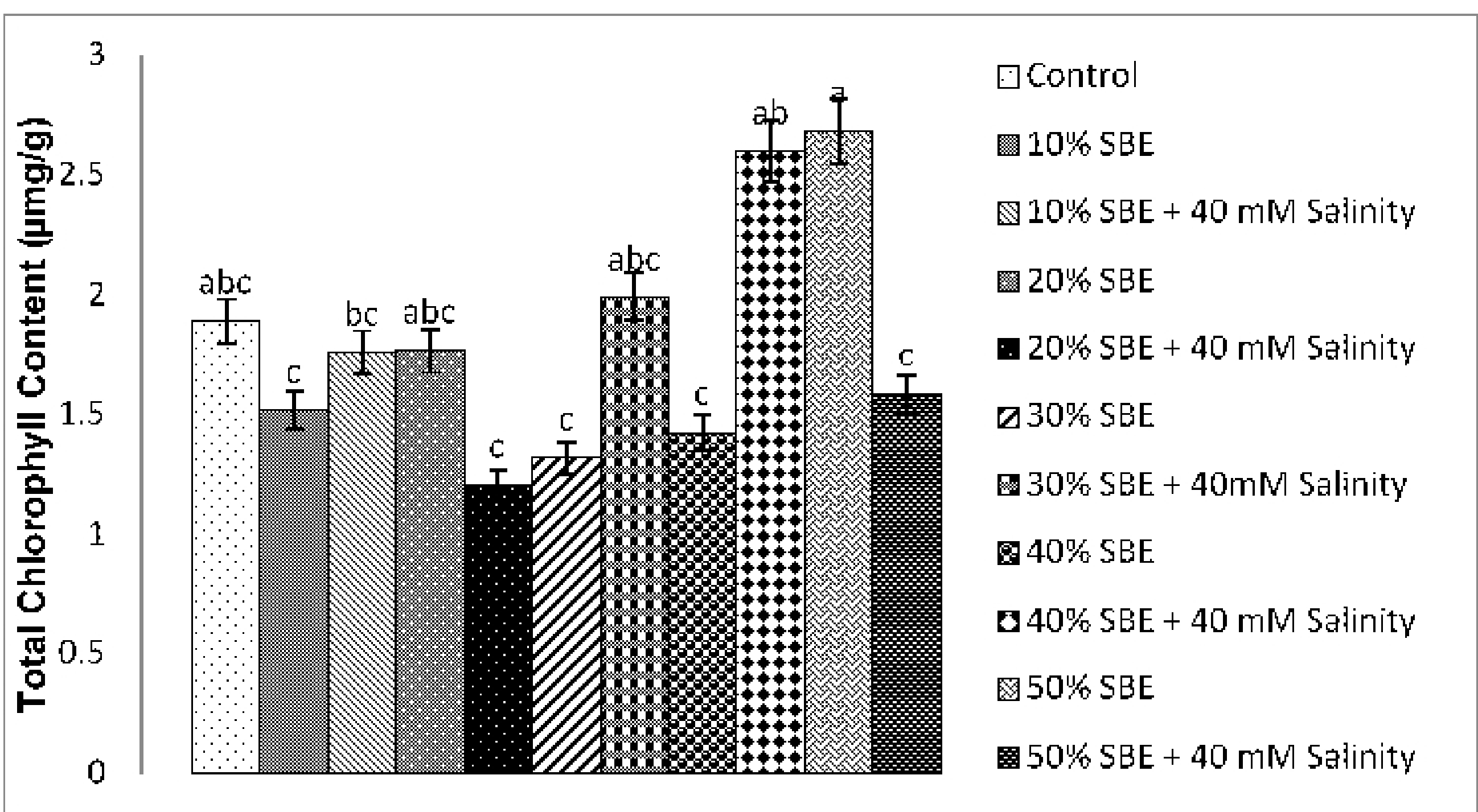

Figure 2. Effect of sugar beet extract on total chlorophyll contents under induced salinity stress. Vertical bars represent SE.

\section{Figure}




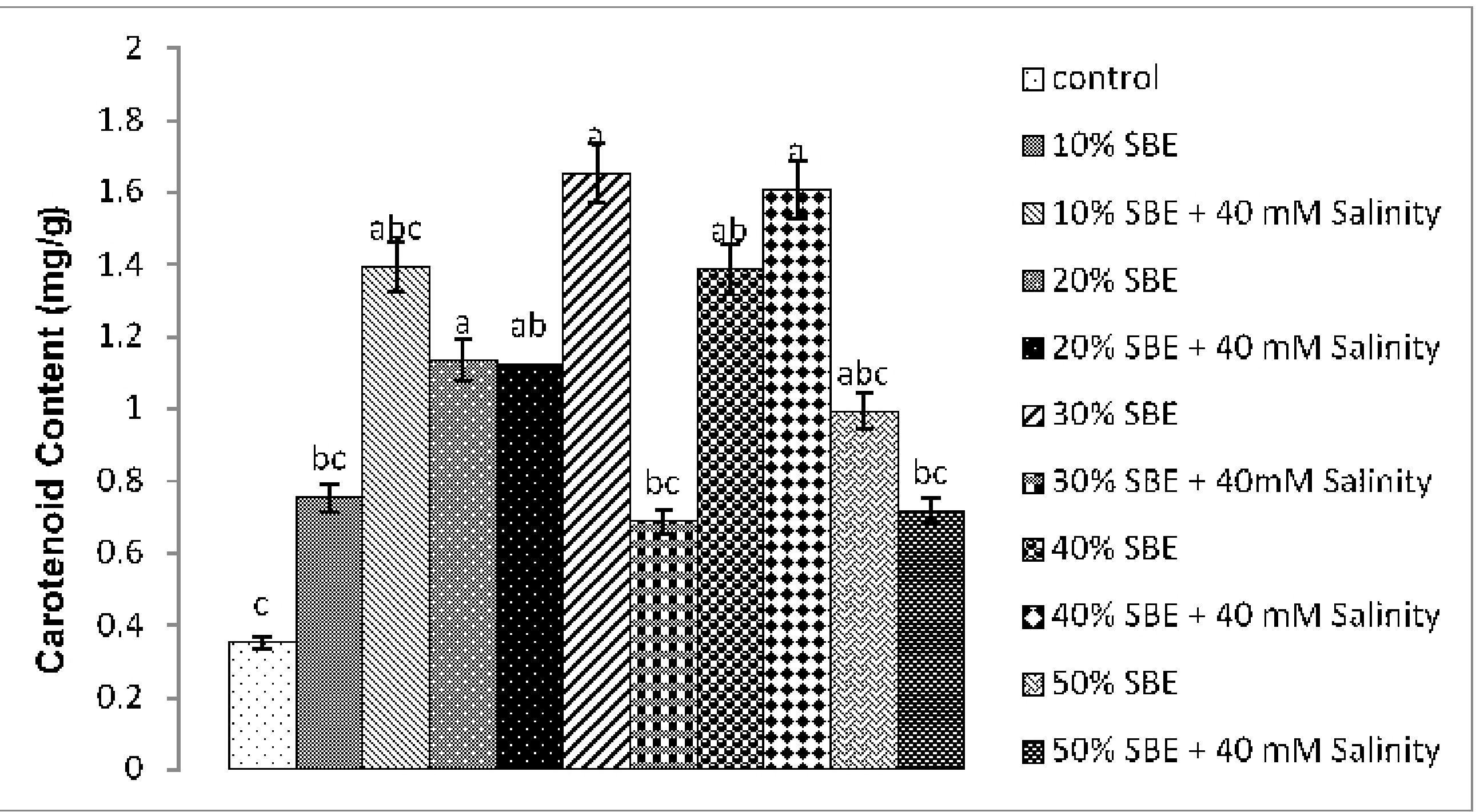

Figure 3. Effect of sugar beet extract on carotenoid content under induced salinity stress. Vertical bars represent SE.

Figure 


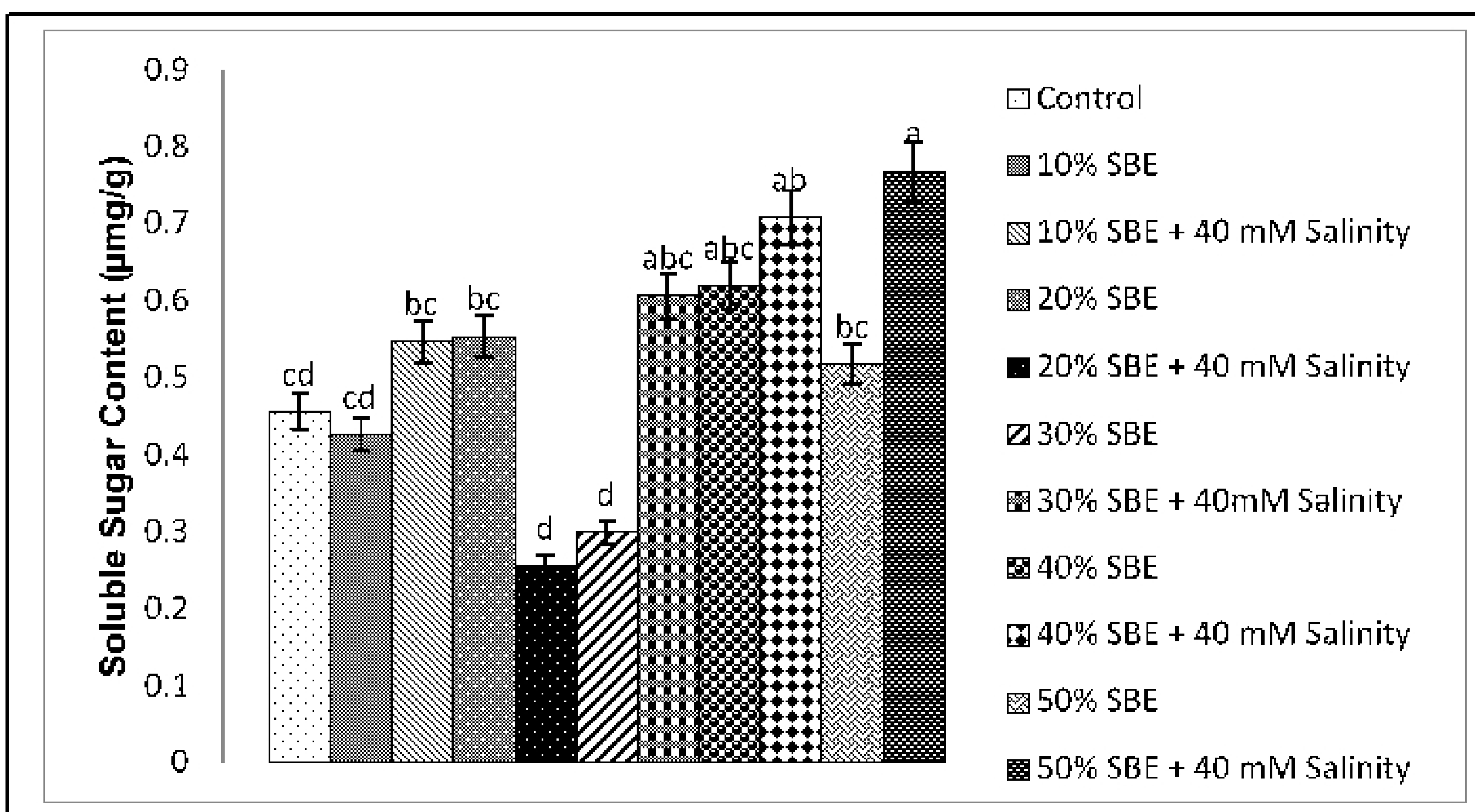

Figure 4. Effect of sugar beet extract on soluble sugar content under induced salinity stress. Vertical bars represent SE.

Figure 


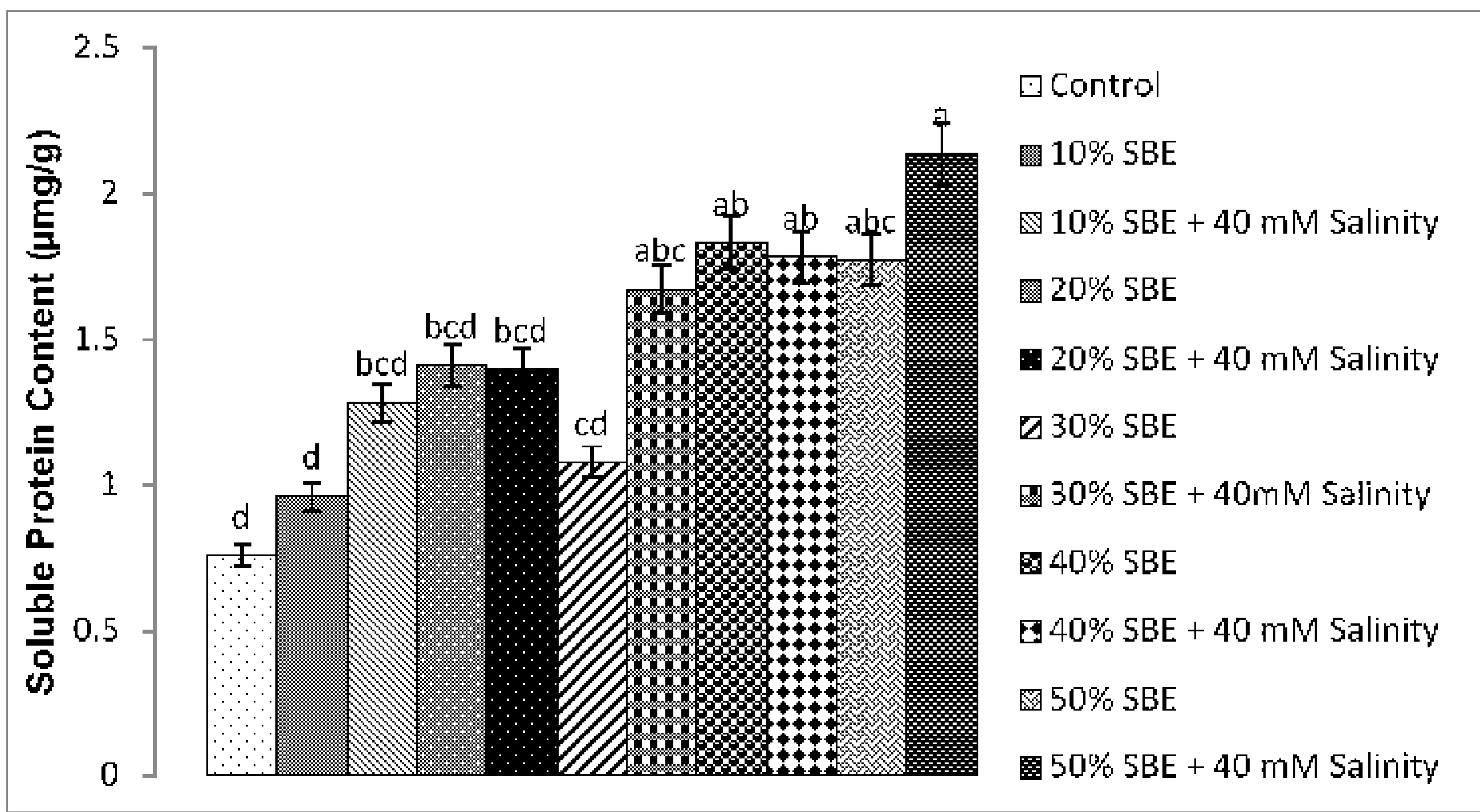

Figure 5. Effect of sugar beet extract on soluble protein content under induced salinity stress. Vertical bars represent SE. 


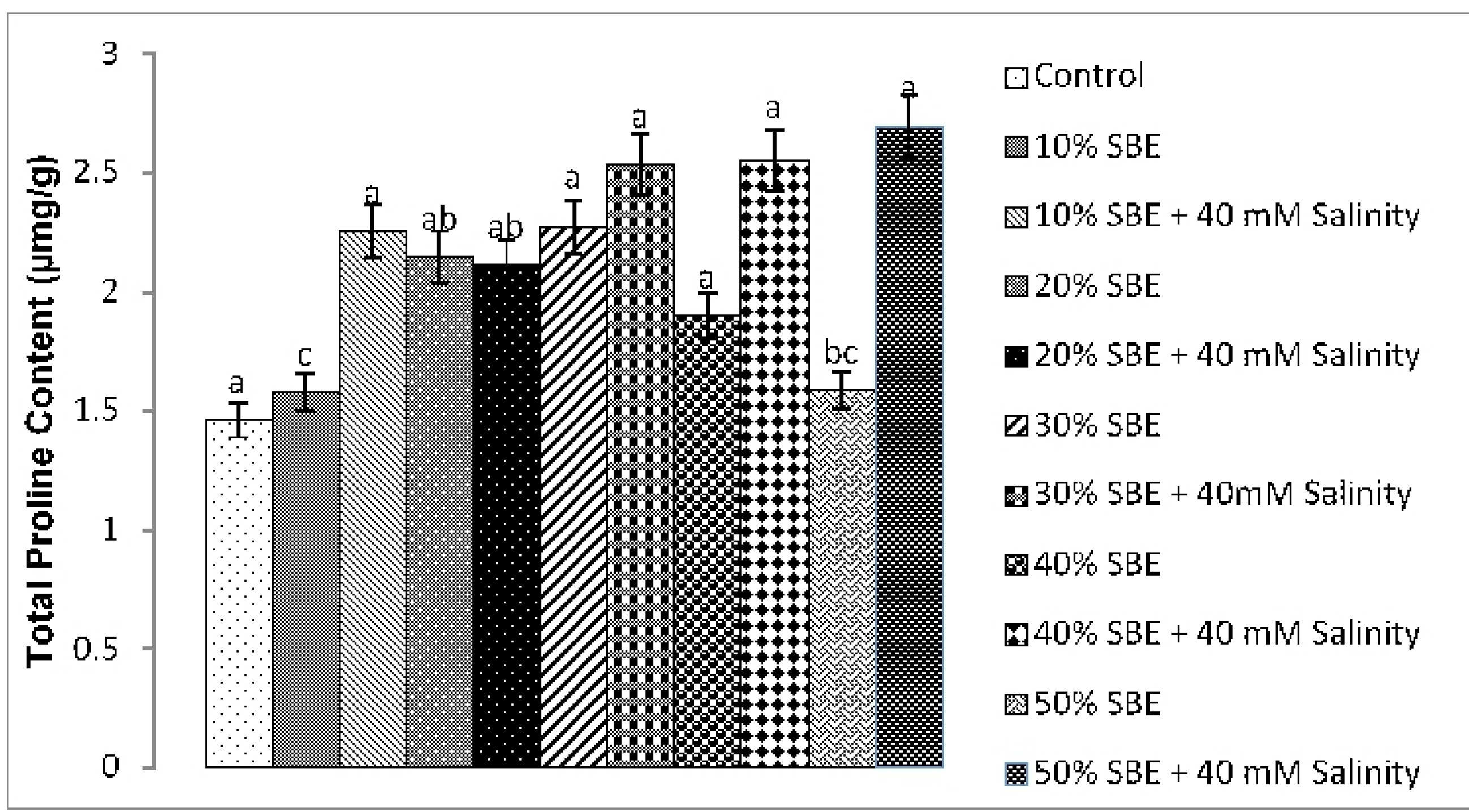

Figure 6. Effect of sugar beet extract on total proline contents under induced salinity stress. Vertical bars represent SE. 


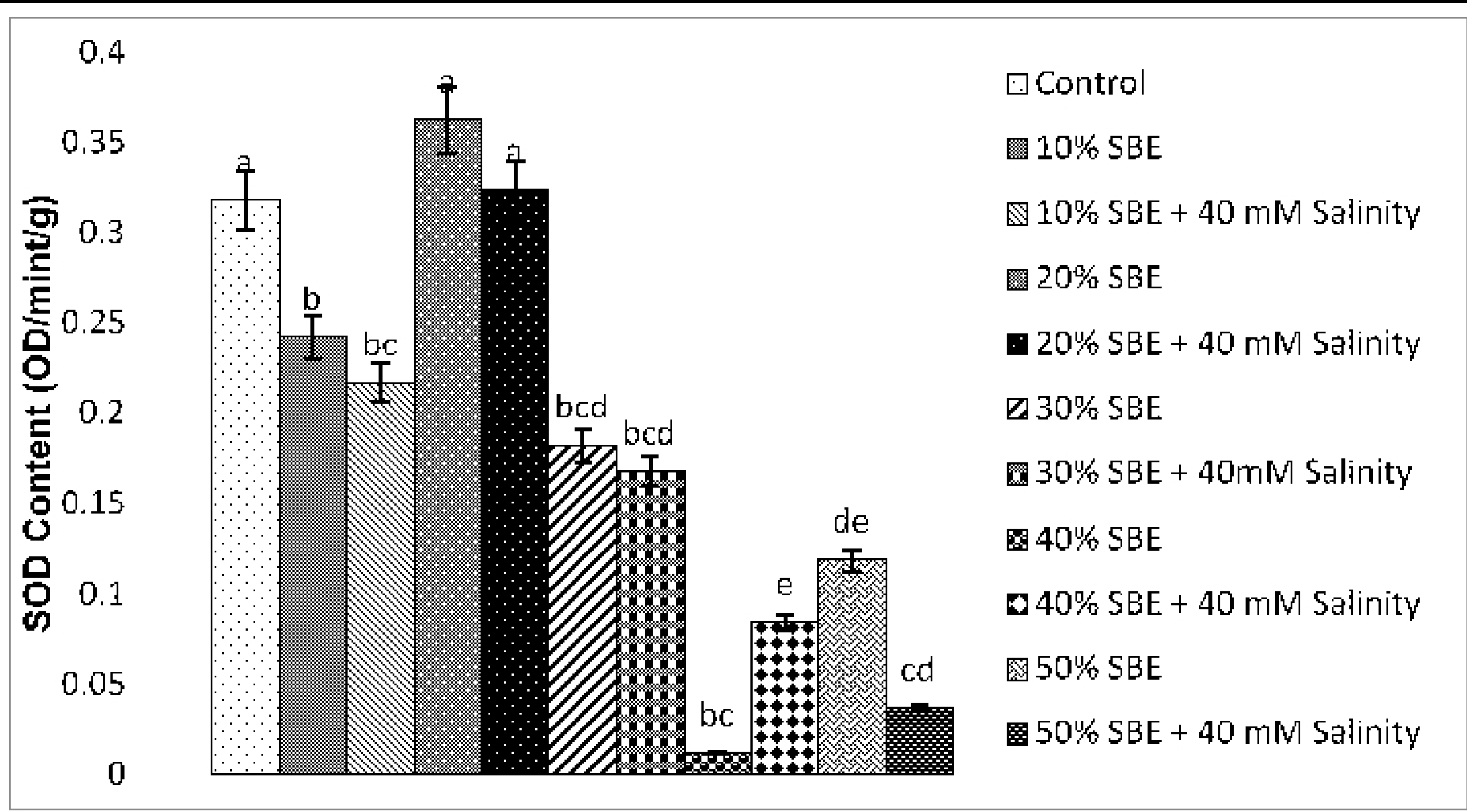

Figure 7. Effect of sugar beet extract on superoxide dismutase under induced salinity stress. Vertical bars represent SE.

Figure 


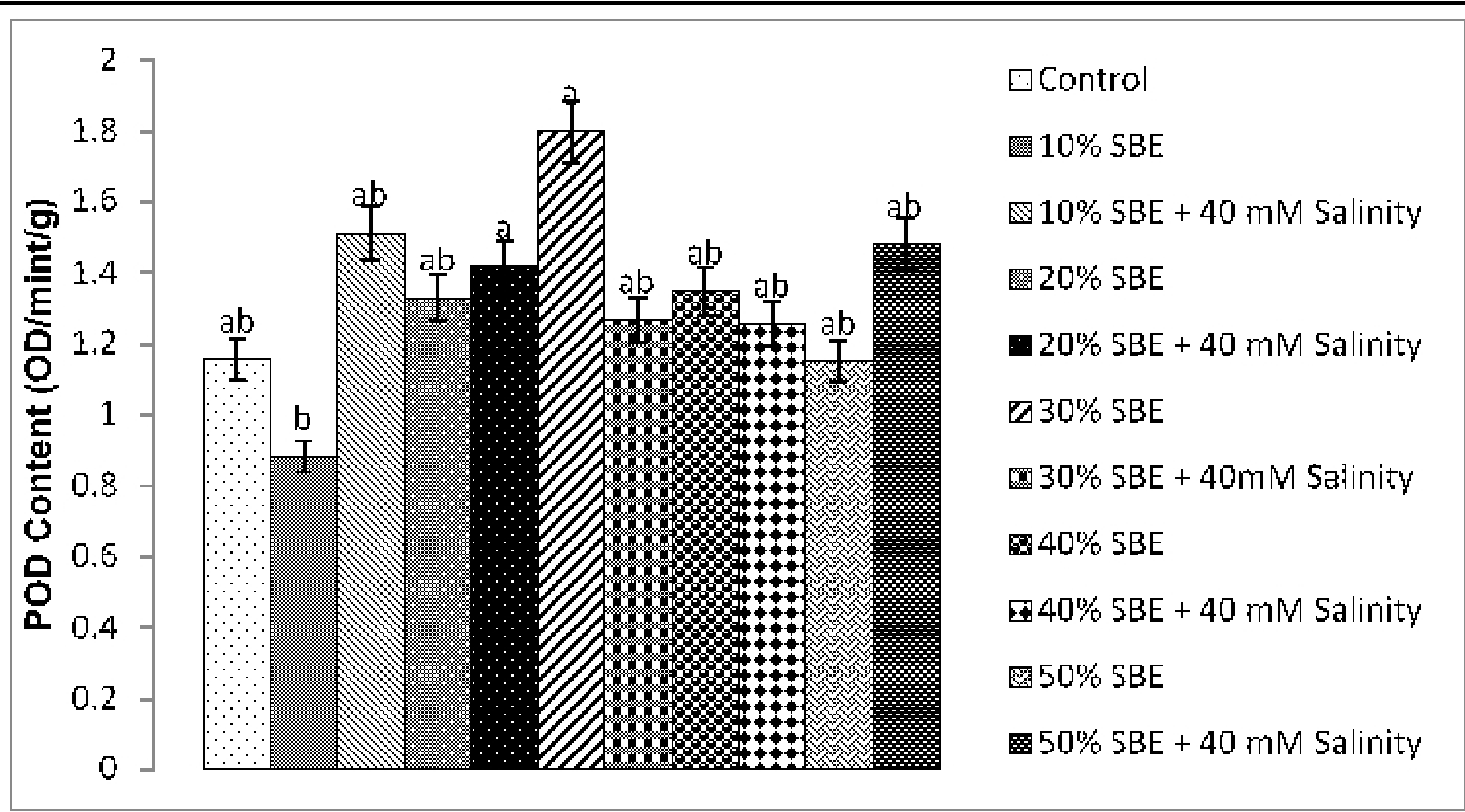

Figure 8. Effect of sugar beet extract on peroxidase under induced salinity stress. Vertical bars represent SE.

\section{Figure}




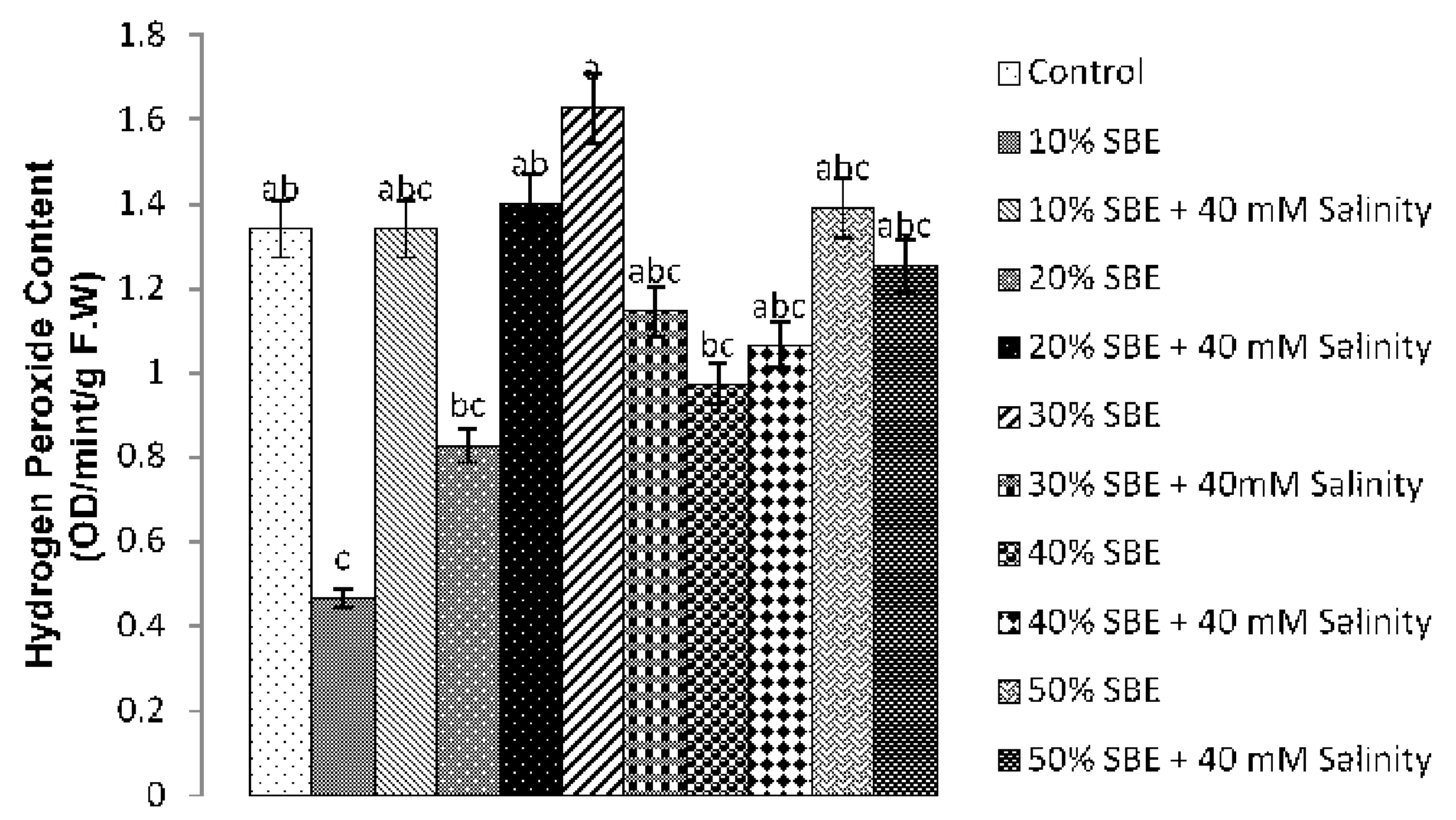

Figure 9. Effect of sugar beet extract on hydrogen peroxide under induced salinity stress. Vertical bars represent SE. 


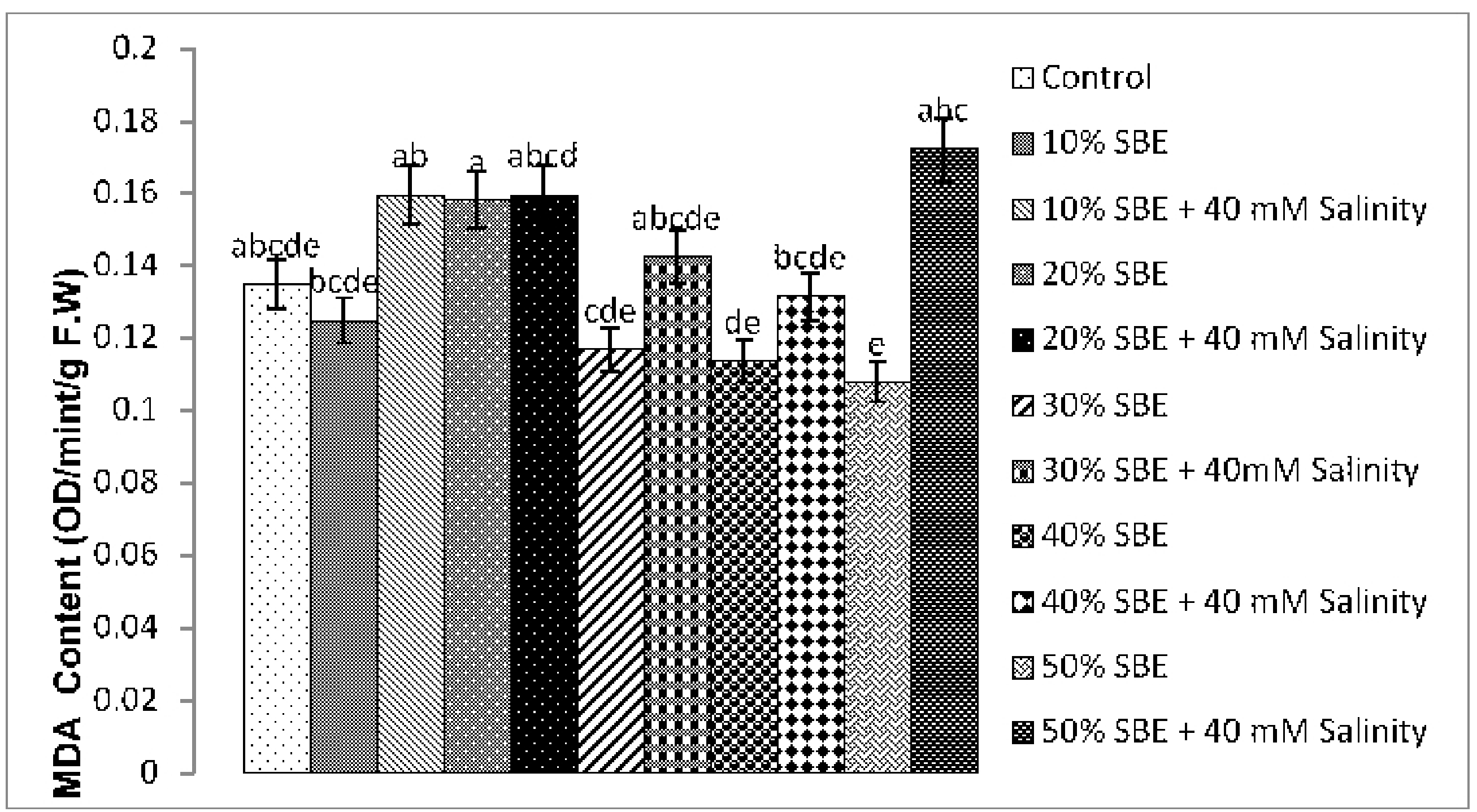

Figure 10. Effect of sugar beet extract on MDA content under induced salinity stress. Vertical bars represent SE.

Figure 